See discussions, stats, and author profiles for this publication at: https://www.researchgate.net/publication/321586254

\title{
Kinerja Ruas Jalan Sultan Alauddin untuk 10 Tahun Mendatang Dengan Menggunakan Program Analisis Lalu Lintas KAJI \& Power Simulation (PSIM)
}

Thesis · December 2017

DOI: 10.13140/RG.2.2.21391.48800

CITATIONS

0

1 author:

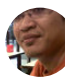

Abdul Hafid Hasim

Universitas Negeri Makassar

7 PUBLICATIONS OCITATIONS

SEE PROFILE

Some of the authors of this publication are also working on these related projects:

Project Factors Affecting Subjective Norms in Use and Have a Private Vehicle in Makassar, Indonesia View project
READS

1,984 


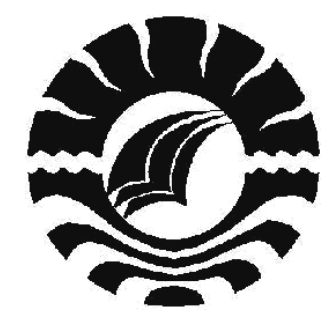

SKRIPSI

KINERJA RUAS JALAN SULTAN ALAUDDIN

UNTUK 10 TAHUN MENDATANG DENGAN MENGGUNAKAN

PROGRAM ANALISIS LALU LINTAS KAJI \& POWER SIMULATION (POWERSIM)

ABDUL HAFID HASIM

042104016

FAKULTAS TEKNIK

UNIVERSITAS NEGERI MAKASSAR

2008 
KINERJA RUAS JALAN SULTAN ALAUDDIN

UNTUK 10 TAHUN MENDATANG DENGAN MENGGUNAKAN

PROGRAM ANALISIS LALU LINTAS KAJI \& POWER

SIMULATION (POWERSIM)

\author{
SKRIPSI \\ Diajukan untuk memenuhi persyaratan guna Memperoleh \\ gelar Sarjana Pendidikan pada JurusanPendidikan \\ Teknik Sipil dan Perencanaan Fakultas Teknik \\ Universitas Negeri Makassar
}

ABDUL HAFID HASIM

042104016

\title{
PENDIDIKAN TEKNIK SIPIL DAN PERENCANAAN \\ FAKULTAS TEKNIK \\ UNIVERSITAS NEGERI MAKASSAR \\ NOVEMBER 2008
}




\section{DAFTAR ISI}

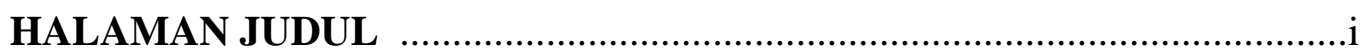

LEMBAR PENGESAHAN ...................................................................ii

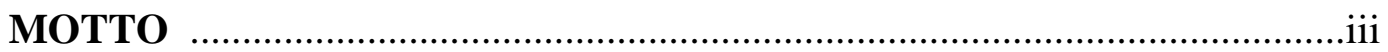

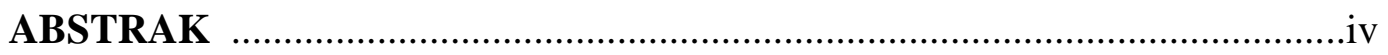

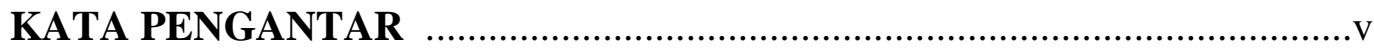

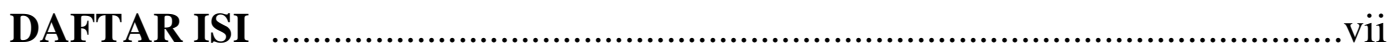

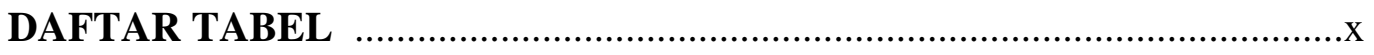

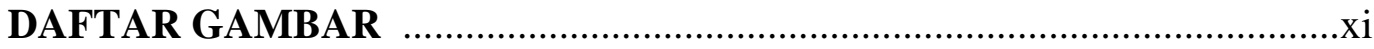

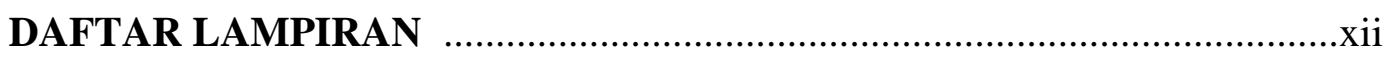

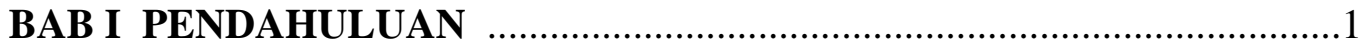

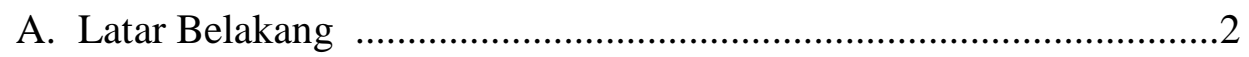

B. Identifikasi dan Batasan Masalah ....................................................

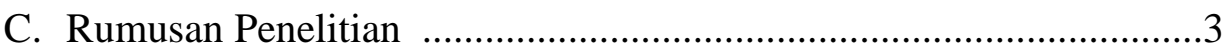

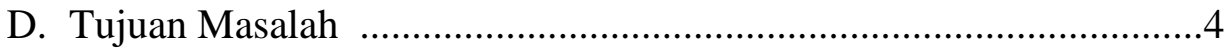

E. Manfaat Penelitian ...................................................................

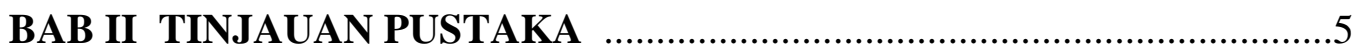

A. Definisi dan Karakteristik Jalan Perkotaan .......................................5

B. Karakteristik Arus Lalu Lintas ....................................................10

1. Volume Lalu Lintas ………………………………................10

2. Komposisi Lalu Lintas ..........................................................10 
3. Kecepatan Lalu Lintas .......................................................13

4. Kepadatan Lalu Lintas .......................................................14

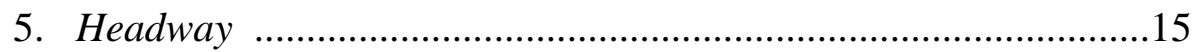

C. Analisa Operasional dan Perencanaan ...........................................16

1. Hambatan Samping .............................................................. 16

2. Kecepatan Arus Bebas ......................................................17

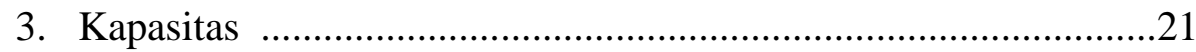

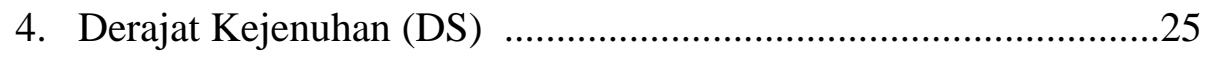

5. Kecepatan dan waktu Tempuh ..............................................26

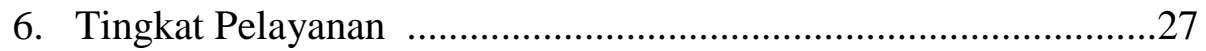

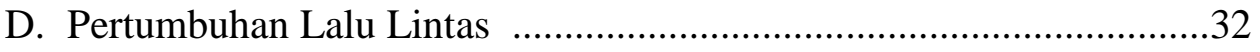

1. Peningkatan Jumlah Kendaraan Bermotor ..................................32

2. Variasi Jarak Kendaraan .......................................................33

E. Peramalan Lalu Lintas .............................................................36

1. Analisis Arus Lalu Lintas .....................................................36

2. Tahun Perencanaan .............................................................. 37

3. Pertumbuhan Lalu Lintas Normal dan Kecenderungan ...............37

4. Peramalan Kecenderungan di Masa Datang ..............................38

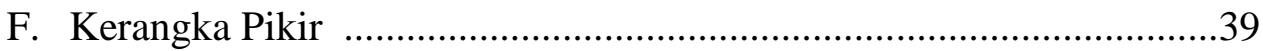

BAB III METODE PENELITIAN ...................................................40

A. Bentuk, Waktu dan Lokasi Penelitian .............................................40

B. Definisi Variabel Operasional ....................................................41 


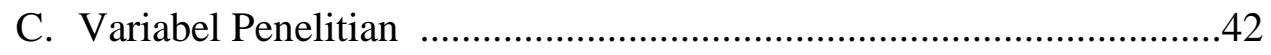

D. Jenis dan Teknik Pengumpulan Data ..................................................43

E. Teknik Analisa Data .........................................................................46

BAB IV HASIL PENELITIAN DAN PEMBAHASAN ............................52

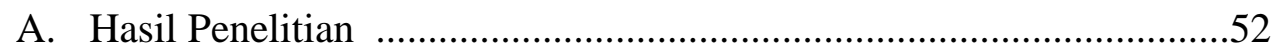

B. Pembahasan Hasil Penelitian ..........................................................55

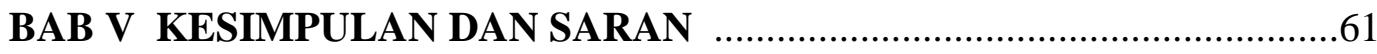

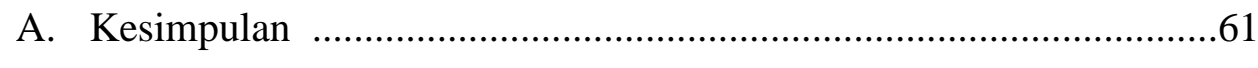

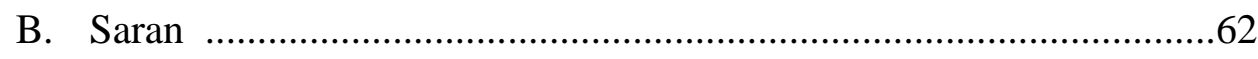

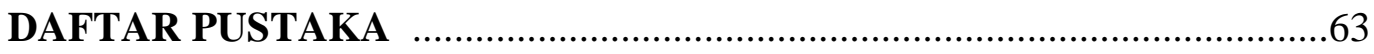

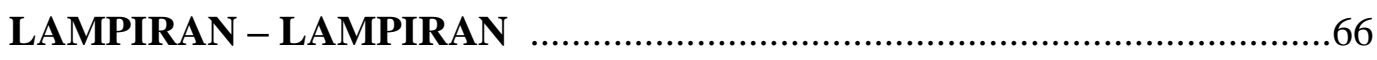

RIWAYAT HIDUP 


\section{DAFTAR TABEL}

\begin{tabular}{|c|c|c|}
\hline $\begin{array}{c}\text { Nomor } \\
\text { Tabel }\end{array}$ & Keterangan & Hal. \\
\hline 1 & Jalan Tipe I & 7 \\
\hline 2 & Jalan Tipe II & 7 \\
\hline 3 & Nilai Normal untuk Komposisi Lalu Lintas & 11 \\
\hline 4 & EMP untuk Jalan Perkotaan Tak Terbagi & 12 \\
\hline 5 & EMP untuk Jalan Perkotaan Terbagi dan Satu Arah & 12 \\
\hline 6 & Kelas Hambatan Samping untuk Jalan Perkotaan & 17 \\
\hline 7 & Kec. Arus Bebas Dasar $\left(\mathrm{FV}_{0}\right)$ untuk Jalan Perkotaan & 18 \\
\hline 8 & Penyesuaian Kec. Arus Bebas untuk Lebar Lalu Lintas $\left(\mathrm{FV}_{\mathrm{w}}\right)$ & 19 \\
\hline 9 & $\begin{array}{l}\text { Faktor Penyesuaian Kec. Arus Bebas untuk Hambatan Samping } \\
\text { dengan Jarak Kereb Penghalang }\left(\mathrm{FFV}_{\mathrm{SF}}\right)\end{array}$ & 20 \\
\hline 10 & $\begin{array}{l}\text { Faktor Penyesuaian Kec. Arus Bebas untuk Ukuran Kota } \\
\left(\mathrm{FFV}_{\mathrm{CS}}\right)\end{array}$ & 20 \\
\hline 11 & Kapasitas Jalan $\left(\mathrm{C}_{\mathrm{o}}\right.$ ) Jalan Perkotaan & 22 \\
\hline 12 & Faktor Penyesuaian Kapasitas Lebar Jalur lalu Lintas $\left(\mathrm{FC}_{\mathrm{W}}\right)$ & 23 \\
\hline 13 & Faktor Penyesuaian Pemisah Arah ( $\mathrm{FC}_{\mathrm{SP}}$ ) & 23 \\
\hline 14 & $\begin{array}{l}\text { Faktor Penyesuaian kapasitas untuk Hambatan Samping dan } \\
\text { Jarak Kereb - Penghalang }\left(\mathrm{FC}_{\mathrm{SF}}\right)\end{array}$ & 24 \\
\hline 15 & Faktor Penyesuaian Kapasitas untuk Ukuran Kota ( $\left.\mathrm{FC}_{\mathrm{CS}}\right)$ & 25 \\
\hline 16 & $\begin{array}{l}\text { Tingkat Pelayanan Berdasarkan Kecepatan Bebas dan Tingkat } \\
\text { Kejenuhan Lalu Lintas }\end{array}$ & 29 \\
\hline 17 & Tingkat Pelayanan Berdasarkan Kecepatan Rata - Rata & 29 \\
\hline 18 & Karakteristik Tingkat Pelayanan & 30 \\
\hline 19 & Waktu Penelitian & 40 \\
\hline
\end{tabular}




\section{DAFTAR GAMBAR}

\begin{tabular}{|c|l|c|}
\hline $\begin{array}{c}\text { Nomor } \\
\text { Gambar }\end{array}$ & \multicolumn{1}{|c|}{ Keterangan } & Hal. \\
\hline 1 & $\begin{array}{l}\text { Grafik Kecepatan Sebagai Fungsi Dari DS Untuk Jalan } \\
\text { Banyak Lajur Dan Satu Arah }\end{array}$ & 26 \\
\hline 2 & $\begin{array}{l}\text { Hubungan Antara Kecepatan, Tingkat Pelayanan Dan Rasio } \\
\text { Volume Terhadap Kapasitas Untuk Jalan }\end{array}$ & 31 \\
\hline 3 & Siklus Perubahan Pola Perjalanan. & 35 \\
\hline 4 & Peramalan Arus Lalu Lintas & 36 \\
\hline 5 & Skema Kerangka Pikir & 39 \\
\hline 6 & Lokasi Penelitian & 41 \\
\hline 7 & Program Analisis Lalu Lintas ( KAJI ) & 47 \\
\hline 8 & Program Power Simulation & 56 \\
\hline 9 & Grafik Analisis Data Dengan Power Simulation & 57 \\
\hline 10 & Kondisi I & 58 \\
\hline 11 & Kondisi II & \multicolumn{1}{|c|}{} \\
\hline & & \multicolumn{1}{|c|}{} \\
\hline
\end{tabular}




\section{DAFTAR LAMPIRAN}

\begin{tabular}{|c|l|c|}
\hline $\begin{array}{c}\text { Nomor } \\
\text { Lampiran }\end{array}$ & \multicolumn{1}{|c|}{ Keterangan } & Hal. \\
\hline 1 & Sketsa Lokasi Penelitian & 66 \\
\hline 2 & Tabel Data Lapangan Volume Lalu Lintas & 67 \\
\hline 3 & Tabel Data Lapangan Volume Lalu Lintas ( SMP) & 75 \\
\hline 4 & Tabel Penentuan Volume Lalu Lintas Jam Puncak & 83 \\
\hline 5 & Rekapitulasi Volume Lalu Lintas Jam Puncak & 87 \\
\hline 6 & Tabel Hambatan Samping & 88 \\
\hline 7 & Tabel Kecepatan Rata-Rata Waktu Kendaraan $(V t)$ & 92 \\
\hline 8 & Tabel Kecepatan Rata-Rata Ruang Kendaraan $(V s)$ & 93 \\
\hline 9 & Program Analisis Ruas Jalan KAJI & 94 \\
\hline 10 & Program Analisis Power Simulation & 94 \\
\hline 11 & Tabel Prediksi Data Arus Lalu Lintas Dengan Program & 95 \\
\hline 12 & Power Simulation ( Dalam SMP ) & 99 \\
\hline 13 & Fintas Ruas Jalan Perkotaan KAJI & 104 \\
\hline 14 & Formulir UR-3 : Analisis data KAJI Senin Ke-52 & 105 \\
\hline 15 & Formulir UR-3 : Analisis data KAJI Senin Ke-104 & 106 \\
\hline 16 & Formulir UR-3 : Analisis data KAJI Senin Ke-132 & 107 \\
\hline 17 & Formulir UR-3 : Analisis data KAJI Senin Ke-156 & 108 \\
\hline 18 & Formulir UR-3 : Analisis data KAJI Senin Ke-195 & 109 \\
\hline 19 & Formulir UR-3 : Analisis data KAJI Kondisi I & 110 \\
\hline
\end{tabular}




\begin{abstract}
ABSTRAK
Abdul Hafid Hasim. 2008. Kinerja Ruas Jalan Sultan Alauddin Untuk 10 Tahun Mendatang Dengan Menggunakan Program Analisis Lalu Lintas KAJI \& Power Simulation (PowerSim). Skripsi. Sipil dan Perencanaan, Fakultas Teknik, Universitas Negeri Makassar. Dr. H. Gufran Darma Dirawan, ST, M EMD dan Ir. H. M. Ichsan Ali, MT. Permasalahan yang diangkat yaitu bagaimana kinerja ruas Jalan Sultan Alauddin Kota Makassar 10 tahun mendatang. Variabel dalam penelitian ini yaitu arus lalu lintas, kecepatan kendaraan, hambatan samping, dan geometrik jalan. Teknik analisa data yang digunakan yaitu Program Analisis Lalu Lintas KAJI untuk menghitung kinerja ruas jalan yakni kapasitas serta derajat kejenuhan dan Program Power Simulation untuk menganalisis pertumbuhan arus lalu lintas. Hasil penelitian menunjukkan jam puncak arus lalu lintas 3122 smp/jam dari jam 07.00 - 08.00. Frekuensi kejadian hambatan samping 1195 kali kejadian per jam. Pertumbuhan arus lalu lintas diperkirakan memiliki kecenderungan meningkat untuk tiap minggu sebesar 0,48 \%. Tingkat pelayanan ruas jalan untuk senin ke-0 sebelum pelebaran masuk kategori $\mathrm{C}$ dengan kapasitas jalan 5806,56 smp/jam dan titik jenuh ruas jalan terjadi pada senin ke-132 dengan kategori $\mathrm{F}$ dengan arus lalu lintas $5809 \mathrm{smp} / \mathrm{jam}$, Setelah pelebaran jalan tingkat pelayanan kembali ke kategori C pada senin ke-132 dengan kapasitas 7867,80 smp/jam dan titik jenuh ruas jalan setelah pelebaran terjadi pada senin ke-195 kategori F dengan arus lalu lintas 7866 smp/jam. Sebagai kesimpulan bahwa kinerja ruas jalan Sultan Alauddin mengalami kecenderungan kapasitas dan tingkat pelayanan terus menurun dari kategori $\mathrm{C}$ ke kategori $\mathrm{F}$.
\end{abstract}




\section{BAB I}

\section{PENDAHULUAN}

\section{A. Latar Belakang Masalah}

Kota Makassar yang menyandang fungsi utama yaitu Ibukota Propinsi Sulawesi Selatan dan pusat pelayanan Kawasan Timur Indonesia, berkembang menjadi kota metropolitan dengan jumlah penduduk lebih dari 1,2 juta orang dengan laju pertumbuhan penduduk $1.79 \%$ per tahun. (BPS Kota Makassar tahun 2007). Keadaan ini mendorong aktivitas dan dinamika penduduk semakin tinggi dan cepat. Pertumbuhan penduduk mendorong pertumbuhan jumlah kendaraan baik roda dua maupun roda empat yang tidak seimbang dengan kapasitas jalan sehingga mengakibatkan penurunan tingkat pelayanan jalan pada jam-jam sibuk. Namun dengan berbagai keterbatasan yang dimiliki, Pemerintah Kota Makassar tidak mampu mengimbangi dan menyediakan berbagai kebutuhan masyarakat terutama penyediaan prasarana transportasi. Jalan merupakan salah satu faktor penentu kemajuan pembangunan diharapkan mempunyai kondisi yang ideal agar mampu memberikan kenyamanan, kelancaraan dan keamanan bagi pemakai jalan. Kondisi ideal terjadi apabila lebar lajur tidak kurang dari 3,5 meter, kebebasan lateral tidak kurang dari 1,75 meter, standard geometrik jalan baik, hanya kendaraan ringan yang menggunakan jalan dan tidak ada batas kecepatan kendaraan.

Hal lain yang merupakan penyebab terjadinya penurunan tingkat pelayanan jalan ialah penggunaan ruang jalan/ROW yang tidak sebagaimana mestinya antara 
lain untuk parkir, pedagang kaki lima, bengkel hingga tempat menaikkan dan menurunkan penumpang. Keadaan yang demikian mengakibatkan penggunaan jalur jalan yang ada melampaui kapasitas jalan.

Dalam keadaan keterbatasan jaringan jalan dan volume kendaraan yang semakin padat, maka angkutan jalan raya menjadi lamban dengan waktu perjalanan panjang dan relatif mahal antara lain karena masih diperlukan penggantian lebih dari dua kali. Lebih jauh hal ini akan menimbulkan penurunan tingkat pelayanan dari jalan raya yang ada utamanya disekitar kawasan pusat-pusat kegiatan serta meningkatnya biaya operasi dari setiap kendaraan angkutan umum maupun kendaraan angkuatan pribadi dan bertambah lamanya waktu pencapaian ke suatu tempat.

Pada saat ini terdapat 2 ruas jalan arteri primer yang memasuki Kota Makassar yaitu Jl. Perintis Kemerdekaan dari arah timur laut Kota Makassar ke Kab. Maros dan J1. Sultan Alauddin dari arah tenggara Kota Makassar ke Kab. Gowa. Fungsi jalan ini sangat vital oleh karena keduanya menampung arus lalu lintas dari luar kota ke pusat kota.

Yang dapat disimpulkan sebagai penyebab timbulnya problem transportasi karena tingkat pertumbuhan sarana transportasi yang tidak bisa mengejar tingginya tingkat pertumbuhan prasarana transportasi.

Berdasarkan dari fenomena yang telah diuraikan diatas, maka judul yang diangkat adalah : “Kinerja Ruas Jalan Sultan Alauddin untuk 10 Tahun Mendatang (Dengan Program Analisis Lalu Lintas KAJI)” 


\section{B. Identifikasi dan Batasan Masalah}

Dengan laju pertumbuhan penduduk 1,79 \% pertahun (BPS Kota Makassar tahun 2007) mendorong meningkatnya aktivitas dan dinamika yang semakin tinggi dan cepat mengakibatkan pertumbuhan kendaraan yang tidak berimbang dengan kapasitas jalan yang ada. Penggunaan ruang jalan/ROW yang tidak sebagaimana mestinya anatara lain untuk parkir, pedagang kaki lima, bengkel hingga temapt menaikkan dan menurungkan penumpang. Angkutan jalan raya menjadi lamban dan waktu perjalanan panjang dan relatif mahal karena diperlukan penggatian lebih dari dua kali juga ikut mengaklibatkan penurunan tingkat pelayanan jalan.

Untuk menghindari agar penulisan ini tidak mempunyai ruang lingkup yang terlalu luas, maka diberikan batasan-batasan masalah yaitu kondisi dan tingkat pertumbuhan arus lalu lintas pada ruas Jalan Sultan Alauddin Kota Makassar pada setiap hari senin.

\section{Rumusan Masalah}

Berdasarkan latar belakang dan judul yang dikemukakan, maka rumusan masalah dinyatakan dalam bentuk pertanyaan yaitu :

1. Bagaimana kondisi arus lalu lintas pada ruas Jalan Sultan Alauddin Kota Makassar hingga 10 tahun mendatang?

2. Bagaimana tingkat pertumbuhan arus lalu lintas ruas Jalan Sultan Alauddin Kota Makassar hingga 10 tahun mendatang? 


\section{Tujuan Penelitian}

Penelitian ini bertujuan untuk :

1. Mengevaluasi kinerja ruas Jalan Sultan Alauddin dengan menentukan besarnya kapasitas, derajat kejenuhan, kecepatan dan tingkat pelayanan.

2. Mengetahui tingkat pertumbuhan arus lalu lintas pada ruas Jalan Sultan Alauddin.

\section{E. Manfaat Hasil Penelitian}

1. Sebagai bahan referensi bagi penelitian yang lebih lanjut.

2. Untuk menambah pengetahuan dan pengalaman khususnya dalam penulisan karya ilmiah.

3. Sebagai bahan kajian dan masukan bagi instansi terkait, seperti Dinas Prasarana Wilayah, Direktorat Jenderal Bina Marga dan Dinas Perhubungan Kota Makassar.

4. Dapat berguna bagi perkembangan Ilmu Teknik Sipil khususnya Teknik Lalu lintas dan Teknik Jalan Raya. 


\section{BAB II}

\section{TINJAUAN PUSTAKA}

\section{A. Definisi dan Karakteristik Jalan Perkotaan}

Menurut MKJI (1997) jalan perkotaan didefinisikan sebagai jalan yang terdapat perkembangan secara permanen dan terus menerus di sepanjang jalan atau hampir seluruh jalan, minimum pada satu sisi jalan, baik berupa lahan atau bukan. Yang termasuk dalam kelompok jalan perkotaan adalah jalan yang berada didekat pusat perkotaan dengan jumlah penduduk lebih dari 100.000 jiwa. Jalan di daerah perkotaan dengan jumlah penduduk yang kurang dari 100.000 jiwa juga dapat digolongkan pada kelompok ini jika perkembangan jalan tersebut bersifat permanen dan terus menerus.

Jalan dikelompokkan sesuai fungsi jalan. Fungsi jalan dikelompokkan sebagai berikut :

1. Jalan Arteri : jalan yang melayani lalu lintas khususnya melayani angkutan jarak jauh dengan kecepatan rata-rata tinggi jumlah kendaraan yang dibatasi.

2. Jalan Kolektor : jalan yang melayani lalu lintas terutama melayani angkutan jarak sedang kecepatan rata-rata sedang serta jumlah akses yang masih dibatasi.

3. Jalan Lokal : jalan yang melayani angkutan setempat terutama angkutan jarak pendek dan kecepatan rata-rata rendah serta akses yang tidak dibatasi.

Jadi jalan arteri adalah jalan utama, sedangkan jalan kolektor dan lokal adalah jalan minor. 
Pembagian kelas jalan berdasarkan dimensi dan muatan sumbu yang diatur oleh PP No. 43 tahun 1993 tentang prasarana dan lalu lintas jalan yang merupakan peraturan pelaksanaan dari UULLAJ No. 14/1992, adalah :

\section{Jalan Kelas I}

Jalan arteri yang dapat dilalui kendaraan bermotor termasuk muatan dengan ukuran lebar tidak melebihi 2,5 m, ukuran panjang tidak melebihi $10 \mathrm{~m}$ dan muatan sumbu terberat yang diizinkan lebih besar dari 10 ton.

\section{Jalan Kelas II}

Jalan arteri yang dapat dilalui kendaraan bermotor termasuk muatan dengan ukuran lebar tidak melebihi 2,5 m, ukuran panjang tidak melebihi $18 \mathrm{~m}$ dan muatan sumbu terberat diizinkan 10 ton.

\section{Jalan Kelas IIIA}

Jalan kolektor yang dapat dilalui kendaraan bermotor termasuk muatan dengan ukuran lebar tidak melebihi 2,5 m, ukuran panjang tidak melebihi $18 \mathrm{~m}$ dan muatan sumbu terberat yang diizinkan 8 ton.

\section{Jalan Kelas IIIB}

Jalan kolektor yang dapat dilalui kendaraan bermotor termasuk muatan dengan ukuran lebar tidak melebihi 2,5 m, ukuran panjang tidak melebihi $12 \mathrm{~m}$ dan muatan sumbu terberat yang diizinkan 8 ton. 


\section{Jalan Kelas IIIC}

Jalan kolektor yang dapat dilalui kendaraan bermotor muatan dengan ukuran lebar tidak melebihi 2,5 m, ukuran panjang tidak melebihi $9 \mathrm{~m}$ dan muatan sumbu terberat yang diizinkan 8 ton.

Sesuai dengan klasifikasi fungsional dan perencanaan volume lalu lintas, jalan-jalan tipe I terbagi dalam 2 kelas dan tipe II terbagi dalam 4 kelas adalah sebagai berikut :

Tabel 1. Jalan Tipe I

\begin{tabular}{|c|c|c|}
\hline \multicolumn{2}{|c|}{ Fungsi } & Kelas \\
\hline \multirow{2}{*}{ Primer } & Arteri & 1 \\
\cline { 2 - 3 } & Kolektor & 2 \\
\hline Sekunder & Arteri & 2 \\
\hline
\end{tabular}

Tabel 2. Jalan Tipe II

\begin{tabular}{|c|lc|c|}
\hline \multirow{2}{*}{ Fungsi } & \multicolumn{2}{|c|}{$\begin{array}{c}\text { Volume lalu Lintas } \\
\text { (SMP) }\end{array}$} & Kelas \\
\hline \multirow{2}{*}{ Primer } & Arteri & - & 1 \\
\cline { 2 - 4 } & Kolektor & $>10,000$ & 1 \\
& & $>10,000$ & 2 \\
\hline \multirow{2}{*}{ Sekunder } & Arteri & $<20,000$ & 1 \\
& & $>20,000$ & 2 \\
\cline { 2 - 4 } & Kolektor & $<6,000$ & 2 \\
& & $>500$ & 3 \\
\cline { 2 - 4 } & Jalan Lokal & $<500$ & 4 \\
\hline
\end{tabular}

Sumber : Standar Perencanaan Geometrik Jalan Perkotaan (1992)

Karakteristik suatu jalan akan mempengaruhi kinerja jalan tersebut.

Karakteristik jalan tersebut terdiri dari atas beberapa hal, yaitu : 


\section{Geometrik Jalan}

a. Tipe Jalan menentukan jumlah lajur dan arah pada segmen jalan dan berbagai tipe jalan akan menunjukkan kinerja berbeda pada pembebanan lalu lintas tertentu, misalnya :

- 2-lajur 1-arah (2/1)

- 2-lajur 2-arah tak-terbagi (2/2 UD)

- 4-lajur 2-arah tak-terbagi (4/2 UD)

- 4-lajur 2-arah terbagi (4/2 D)

- 4-lajur 2-arah terbagi (4/2 D)

- 6-lajur 2-arah terbagi (6/2 D)

b. Jalur lalu lintas adalah keseluruhan bagian perkerasan jalan yang diperuntukkan untuk lalu lintas kendaraan, kecepatan arus bebas dan kapasitas meningkat dengan pertambahan lebar jalur lalu lintas.

c. Kereb adalah batas antara jalur lalu lintas dan trotoar yang berpengaruh terhadap dampak hambatan samping pada kapasitas dan kecepatan.

d. Bahu lebar dan kondisi permukaannya mempengaruhi pengunaan bahu, berupa penambahan kapasitas dan kecepatan pada arus tertentu, akibat pertambahan lebar bahu terutama karena pengurangan hambatan samping yang disebabkan kejadian disisi jalan

e. Median adalah pembatas jalan yang membagi lajur dan jalur jalan. Median yang direncanakan dengan baik akan meningkatkan kapasitas. 


\section{Komposisi arus lalu lintas dan pemisah arah}

Volume lalu lintas dipengaruhi komposisi arus lalu lintas, setiap kendaraan yang ada harus dikonversikan menjadi suatu kendaraan standar.

\section{Pengaturan lalu lintas}

Batas kecepatan jarang diberlakukan didaerah perkotaan Indonesia, karenannya hanya sedikit kegiatan samping berpengaruh pada kecepatan arus bebas.

\section{Hambatan samping.}

Banyaknya kegiatan hambatan samping jalan di Indonesia sering menimbulkan konflik, hingga menghambat arus lalu lintas, misalkan :

a. Pejalan kaki

b. Angkutan umum dan kendaraan yang berhenti

c. kendaraan lambat (Becak, sepeda, dan lain-lain)

d. Kendaraan masuk dan keluar dari lahan samping jalan

\section{Perilaku pengemudi dan populasi kendaraan}

Manusia sebagai pengemudi kendaraan merupakan bagian dari arus lalu lintas yaitu pemakai jalan. Faktor psikologis, fisik pengemudi sangat berpengaruh dalam menghadapi situasi arus lalu lintas yang dihadapi. 


\section{B. Karakteristik Arus Lalu Lintas}

\section{Volume lalu Lintas}

Berdasarkan MKJI (1997) volume lalu lintas didefinisikan sebagai jumlah kendaraan yang melalui titik pada jalan per satuan waktu, dinyatakan dalam kend/jam $\left(\mathrm{Q}_{\mathrm{kend}}\right)$, smp/jam $\left(\mathrm{Q}_{\mathrm{smp}}\right)$, LHRT $\left(\mathrm{Q}_{\mathrm{LHRT}}\right)$. Volume lalu lintas dihitung berdasarkan persamaan :

$$
Q=\frac{N}{T}
$$

dimana :

$$
\begin{aligned}
& \mathrm{Q}=\text { Volume }(\text { kend/jam) } \\
& \mathrm{N}=\text { Jumlah Kendaraan }(\text { Kend }) \\
& \mathrm{T}=\text { Waktu Pengamatan }(\text { jam })
\end{aligned}
$$

\section{Komposisi Arus Lalu Lintas}

Menurut Wibowo (2001) komposisi arus lalu lintas didefinisikan sebagai jenis atau tipe suatu kendaraan, baik kendaraan bermotor maupun kendaraan tak bermotor yang melewati suatu ruas jalan.

Kendaraan yang melewati suatu ruas jalan sangat mempengaruhi arus lalu lintas. Unsur utama yang sangat mempengaruhi arus lalu lintas adalah segi ukuran, kekuatan dan kemampuan kendaraan melakukan pergerakan dijalan. Ketiga unsur ini sangat berpengaruh pada perencanaan, pengawasan dan pengaturan sistem transportasi. Nilai normal untuk komposisi lalu lintas dapat dilihat pada Tabel 3. 
Tabel 3. Nilai Normal untuk Komposisi Lalu Lintas

\begin{tabular}{|c|c|c|c|}
\hline $\begin{array}{c}\text { Ukuran Kota } \\
\text { (Juta Penduduk) }\end{array}$ & $\begin{array}{c}\text { LV } \\
(\boldsymbol{\%})\end{array}$ & $\begin{array}{c}\text { HV } \\
(\boldsymbol{\%})\end{array}$ & $\begin{array}{c}\text { MC } \\
(\boldsymbol{\%})\end{array}$ \\
\hline$<0,1$ & 45 & 10 & 45 \\
\hline $0,1-0,5$ & 45 & 10 & 45 \\
\hline $0,5-1,0$ & 53 & 9 & 38 \\
\hline $1,0-3,0$ & 60 & 8 & 32 \\
\hline$>3,0$ & 69 & 7 & 24 \\
\hline
\end{tabular}

Sumber : MKJI (1997)

Penggolongan tipe kendaraan untuk jalan perkotaan berdasarkan MKJI (1997) adalah sebagai berikut :

\section{a. Kendaraan ringan (LV)}

Kendaraan bermotor beroda empat dengan dua gandar berjarak 2 - 3 m (termasuk kendaraan penumpang, opelet, mikrobis, pick-up dan truck kecil sesuai sistem klasifikasi Bina Marga)

\section{b. Kendaraan berat (HV)}

Kendaraan bermotor dengan jarak as lebih dari 3,5 m, biasanya beroda lebih dari 4 (termasuk bis, truk 2 as, truck 3 as dan truk kombinasi sesuai sistem klasifikasi Bina Marga)

\section{c. Sepeda motor (MC)}

Kendaraan bermotor beroda dua atau tiga (termasuk sepeda motor dan kendaraan beroda tiga sesuai sistem klasifikasi Bina Marga) 


\section{d. Kendaraan tak bermotor (UM)}

Kendaraan beroda yang menggunkan tenaga manusia atau hewan (termasuk sepeda, becak, kereta kuda dan kereta dorong sesuai sistem klasifikasi Bina Marga)

Berbagai jenis kendaraan diekuivalenkan ke satuan mobil penumpang (smp) dengan menggunakan faktor ekivalen mobil penumpang (emp), emp adalah faktor yang menunjukkan berbagai tipe kendaraan dibandingkan dengan kendaraan ringan.

Nilai emp untuk berbagai jenis kendaraan dapat dilihat pada Tabel 4 dan Tabel 5.

Tabel 4. Ekivalen Mobil Penumpang (emp) untuk jalan perkotaan tak terbagi

\begin{tabular}{|c|c|c|c|c|}
\hline \multirow{4}{*}{$\begin{array}{c}\text { Tipe jalan } \\
\text { Jalan tak terbagi }\end{array}$} & \multirow{4}{*}{$\begin{array}{l}\text { Arus lalu lintas } \\
\text { total dua arah } \\
\text { (kend/jam) }\end{array}$} & \multicolumn{3}{|c|}{ emp } \\
\hline & & \multirow{3}{*}{ HV } & \multicolumn{2}{|c|}{$\mathrm{MC}$} \\
\hline & & & \multicolumn{2}{|c|}{$\begin{array}{c}\text { Lebar jalur lalu lintas Wc } \\
\text { (m) }\end{array}$} \\
\hline & & & $\leq 6$ & $>6$ \\
\hline Dua-lajur tak-terbagi & 0 & 1.3 & 0.5 & 0.4 \\
\hline$(2 / 2 \mathrm{UD})$ & $\geq 1800$ & 1.2 & 0.35 & 0.25 \\
\hline Empat-lajur tak-terbagi & 0 & 1.3 & \multicolumn{2}{|c|}{0.4} \\
\hline (4/2 UD) & $\geq 3700$ & 1.2 & \multicolumn{2}{|c|}{0.25} \\
\hline
\end{tabular}

Sumber : MKJI (1997)

Tabel 5. Ekivalen Mobil Penumpang (emp) untuk Jalan Perkotaan Terbagi dan Satu Arah

\begin{tabular}{|c|c|c|c|}
\hline Tipe Jalan : & Arus lalu lintas & \multicolumn{2}{|c|}{ emp } \\
\cline { 3 - 4 } $\begin{array}{c}\text { Jalan satu arah dan } \\
\text { Jalan terbagi }\end{array}$ & $\begin{array}{c}\text { per lajur } \\
\text { (kend/jam) }\end{array}$ & HV & MC \\
\hline Dua -lajur satu-arah (2/1) & 0 & 1.30 & 0.40 \\
Empat-lajur terbagi (4/2D) & $\geq 1050$ & 1.20 & 0.25 \\
\hline Tiga -lajur satu-arah (3/1) & 0 & 1.30 & 0.40 \\
Enam-lajur terbagi (6/2D) & $\geq 1100$ & 1.20 & 0.25 \\
\hline
\end{tabular}

Sumber : MKJI (1997) 


\section{Kecepatan Lalu Lintas}

Kecepatan adalah tingkat pergerakan lalu-lintas atau kendaraan tertentu yang sering dinyatakan dalam kilometer per jam. Menurut Abubakar (1999) kecepatan adalah jarak dibagi dengan waktu. Persamaan untuk menentukan kecepatan adalah sebagai berikut ;

$$
V=\frac{d}{t}
$$

dimana :

$$
\begin{aligned}
\mathrm{V} & =\operatorname{Kecepatan}(\mathrm{km} / \mathrm{jam}) \\
\mathrm{d} & =\text { Jarak Tempuh }(\mathrm{km}) \\
\mathrm{t} & =\text { Waktu Tempuh (Jam) }
\end{aligned}
$$

Kecepatan dapat dibagi dalam :

a. Kecepatan titik (Spot Speed) adalah kecepatan sesaat kendaraan berada pada titik/lokasi jalan tertentu.

b. Kecepatan rata-rata perjalanan (Average Travel Speed) dan Kecepatan perjalanan adalah total waktu tempuh kendaraan untuk suatu segemen jalan yang ditentukan. Waktu perjalanan adalah total waktu ketika kendaraan dalam kendaraan bergerak (berjalan) untuk menem[uh suatu segmen jalan.

c. Kecepatan rata-rata ruang (Space Mean Speed) adalah kecepatan rata-rata kendaraan disepanjang jalan yang diamati.

$$
V s=\frac{3,6 n d}{\sum t}
$$


dimana :

$$
\begin{aligned}
\mathrm{Vs} & =\text { Kecepatan rata-rata ruang }(\mathrm{km} / \mathrm{jam}) \\
\mathrm{d} & =\text { Jarak Tempuh (meter) } \\
\mathrm{t} & =\text { Waktu Tempuh (detik) } \\
\mathrm{n} & =\text { Jumlah Kendaraan yang diamati }
\end{aligned}
$$

d. Kecepatan rata-rata waktu (Time Mean Speed) adalah kecepatan rata-rata yang menggambarkan kecepatan rata-rata dari seluruh kendaraan yang melewati titik pengamatan tertentu

$$
V t=\frac{\sum V}{n}
$$

dimana :

$$
\begin{aligned}
\mathrm{Vt} & =\text { Kecepatan rata-rata waktu }(\mathrm{km} / \mathrm{jam}) \\
\mathrm{V} & =\text { Kecepatan kendaraan }(\mathrm{km} / \mathrm{jam}) \\
\mathrm{n} & =\text { Jumlah kendaraan yang diamati }
\end{aligned}
$$

\section{Kepadatan Lalu Lintas}

Menurut Morlok (1991), Kepadatan lalu lintas dapat didefenisikan sebagai jumlah kendaraan yang menempati panjang ruas jalan tertentu atau jalur yang umunya dinyatakan sebagai jumlah kendaraan per kilometer per lajur (jika pada ruas jalan tersebut terdiri dari banyak lajur). Kepadatan merupakan jumlah kendaraan yang diamati dibagi dengan panjang jalan tersebut. Hubungan antara volume, kecepatan dan kepadatan adalah sebagai berikut : 


$$
k=\frac{q}{s}
$$

dimana :

$$
\begin{aligned}
& \mathrm{k}=\text { Kepadatan lalu Lintas }(\mathrm{Kend} / \mathrm{km}) \\
& \mathrm{q}=\text { Jumlah Kendaraan pada lintasan }(\text { Kend } / \mathrm{jam}) \\
& \mathrm{s}=\text { Kecepatan lalu lintas }(\mathrm{Km} / \mathrm{jam})
\end{aligned}
$$

\section{Headway}

Menurut Abubakar (1999), Headway adalah besarnya jarak-antara menentukan kapan seorang pengemudi harus mengurangi kecepatan (mengerem) dan kapan dia dapat mempercepat kendaraan. Waktu-antara kendaraan (time headway) yaitu waktu yang diperlukan antara satu kendaraan dengan kendaraan yang berikutnya untuk melalui satu titik yang tetap.

Waktu-antara dapat dihitung dengan persamaan sebagai berikut :

$$
H t=\frac{1}{q}
$$

dimana :

$$
\begin{aligned}
& \mathrm{Ht}=\text { Waktu-antara kendaraan rata-rata } \\
& \mathrm{Q}=\text { Volume lalu Lintas }
\end{aligned}
$$

Jarak-antara kendaraan (Space headway) yaitu jarak antara bagian depan suatu kendaraan dengan bagian depan kendaraan berikutnya pada suatu saat tertentu. Jarak headway rata-rata dipergunakan, terutama pada suatu situasi dimana terdapat 
nilai yang berbeda diantara pasangan kendaraan dalam suatu arus lalu lintas. Jarakantara kendaraan dapat dihitung dengan persamaan sebagai berikut :

$$
H d=\frac{1}{k}
$$

dimana :

$$
\begin{aligned}
& \mathrm{Hd}=\text { Jarak-antara kendaraan rata-rata } \\
& \mathrm{k}=\text { Kepadatan }
\end{aligned}
$$

\section{Analisa Operasional dan Perencanaan}

\section{Hambatan Samping}

Hambatan samping menurut MKJI (1997) yakni aktivitas samping yang dapat menimbulkan konflik dan berpengaruh terhadap pergerakan arus lalu lintas serta menurunkan kinerja jalan.

Adapaun tipe kejadian hambatan samping adalah :

a. Jumlah pejalan kaki berjalan atau menyeberang sepanjang segmen jalan.

b. Jumlah kendaraan berhenti dan parkir.

c. Jumlah kendaraan bermotor yang masuk dan keluar dari lahan samping jalan dan jalan samping.

d. Arus kendaraan lambat yaitu arus total (kend/jam) sepeda, becak, delman, pedati dan sebagainya.

Tingkat hambatan samping dikelompokkan kedalam lima kelas dari yang rendah sampai sangat tinggi sebagai fungsi dari frekuensi kejadian hambatan samping 
sepanjang segmen jalan yang diamati. Dalam MKJI 1997 kelas hambatan samping dikelompokkan seperti yang ada pada Tabel 6.

Tabel 6. Kelas Hambatan Samping untuk Jalan Perkotaan

\begin{tabular}{|l|c|c|l|}
\hline $\begin{array}{c}\text { Kelas hambatan } \\
\text { samping } \\
\text { (SFC) }\end{array}$ & Kode & $\begin{array}{c}\text { Jumlah berbobot } \\
\text { kejadian per } \\
\text { 200 m perjam } \\
\text { (dua sisi) }\end{array}$ & \multicolumn{1}{|c|}{ Kondisi Khusus } \\
\hline Sangat rendah & VL & $<100$ & $\begin{array}{l}\text { Daerah permukiman ; } \\
\text { Jalan dengan jalan samping }\end{array}$ \\
\hline Rendah & L & $100-299$ & $\begin{array}{l}\text { Daerah permukiman; } \\
\text { Beberapa kendaraan umum dsb. }\end{array}$ \\
\hline Sedang & $\mathrm{M}$ & $300-499$ & $\begin{array}{l}\text { Daerah industri ; } \\
\text { Beberapa toko di sisi jalan }\end{array}$ \\
\hline Tinggi & $\mathrm{H}$ & $500-899$ & $\begin{array}{l}\text { Daerah komersial ; } \\
\text { Aktivitas sisi jalan sangat tinggi }\end{array}$ \\
\hline Sangat tinggi & $\mathrm{VH}$ & $>900$ & $\begin{array}{l}\text { Daerah komersial ; } \\
\text { Aktivitas pasar disamping jalan }\end{array}$ \\
\hline
\end{tabular}

Sumber : MKJI (1997)

\section{Kecepatan Arus Bebas}

Berdasarkan MKJI (1997) kecepatan arus bebas didefinisikan sebagai kecepatan pada tingkat arus nol, yaitu kecepatan yang akan dipilih pengemudi jika mengendarai kendaraan bermotor tanpa dipengaruhi oleh kendaraan bermotor lain di jalan. Persamaan untuk penentuan kecepatan arus bebas mempunyai bentuk umum sebagai berikut :

$$
\mathrm{FV}=\left(\mathrm{FV}_{0}+\mathrm{FV}_{\mathrm{w}}\right) \times \mathrm{FFV}_{\mathrm{SF}} \times \mathrm{FFV}_{\mathrm{CS}}
$$

dimana : 
$\mathrm{FV}=$ Kecepatan arus bebas kendaraan ringan pada kondisi lapangan $(\mathrm{km} / \mathrm{jam})$

$\mathrm{FV}_{0} \quad=$ Kecepatan arus bebas dasar kendaraan ringan pada jalan yang diamati $(\mathrm{km} / \mathrm{jam})$

$\mathrm{FV}_{\mathrm{w}}=$ Penyesuaian kecepatan untuk lebar jalan $(\mathrm{km} / \mathrm{jam})$

$\mathrm{FFV}_{\mathrm{SF}}=$ Faktor penyesuaian akibat hambatan samping dan lebar bahu.

$\mathrm{FFV}_{\mathrm{CS}}=$ Faktor Penyesuaian ukuran kota

Kecepatan arus bebas dasar kendaraan ringan $\left(\mathrm{FV}_{0}\right)$ ditentukan berdasarkan tipe jalan dan jenis kendaraan sesuai dengan Tabel 7.

Tabel 7. Kecepatan arus bebas dasar $\left(\mathrm{FV}_{0}\right)$ untuk jalan perkotaan.

\begin{tabular}{|c|c|c|c|c|}
\hline \multirow[b]{2}{*}{ Tipe Jalan } & \multicolumn{4}{|c|}{ Kecepatan arus bebas dasar $\left(\mathrm{FV}_{0}\right)(\mathrm{km} / \mathbf{j a m})$} \\
\hline & $\begin{array}{c}\text { Kendaraan } \\
\text { Ringan } \\
\text { LV }\end{array}$ & $\begin{array}{c}\text { Kendaraa } \\
\text { n } \\
\text { Berat } \\
\text { HV }\end{array}$ & $\begin{array}{l}\text { Sepeda } \\
\text { Motor } \\
\text { MC }\end{array}$ & $\begin{array}{c}\text { Semua } \\
\text { Kendaraa } \\
\mathbf{n} \\
\text { (rata-rata) }\end{array}$ \\
\hline $\begin{array}{l}\text { Enam-lajur terbagi (6/2 D) } \\
\text { atau } \\
\text { Tiga-Lajur satu-arah }(3 / 1)\end{array}$ & 61 & 52 & 48 & 57 \\
\hline $\begin{array}{l}\text { Enam-lajur terbagi }(6 / 2 \mathrm{D}) \\
\text { atau } \\
\text { Tiga-Lajur satu-arah (3/1) }\end{array}$ & 57 & 50 & 47 & 55 \\
\hline $\begin{array}{l}\text { Empat-lajur tak-terbagi } \\
\text { (4/2 UD) }\end{array}$ & 53 & 46 & 43 & 51 \\
\hline $\begin{array}{l}\text { Dua-lajur tak-terbagi } \\
\text { (2/2 UD) }\end{array}$ & 44 & 40 & 40 & 42 \\
\hline
\end{tabular}

Sumber : MKJI (1997) 
Penyesuaian kecepatan arus bebas untuk lebar lalu lintas berdasarkan lebar jalur lalu lintas efektif kendaraan ringan $\left(\mathrm{FV}_{\mathrm{w}}\right)$ untuk jalan perkotaan dapat dilihat pada tabel 8 .

Tabel 8. Penyesuaian Kecepatan Arus Bebas untuk Lebar lalu Lintas $\left(\mathrm{FV}_{\mathrm{w}}\right)$

\begin{tabular}{|l|c|c|}
\hline \multicolumn{1}{|c|}{ Tipe Jalan } & $\begin{array}{c}\text { Lebar jalur lalu lintas efektif }\left(\mathbf{W}_{\mathbf{c}}\right) \\
(\mathbf{m})\end{array}$ & $\begin{array}{c}\mathbf{F V}_{\mathbf{w}} \\
(\mathbf{k m} / \mathbf{j a m})\end{array}$ \\
\hline & Per lajur & \\
Empat-lajur terbagi & 3.00 & -4.00 \\
atau & 3.25 & -2.00 \\
Jalan satu arah & 3.50 & 0.00 \\
& 3.75 & 2.00 \\
& 4.00 & 4.00 \\
\hline \multirow{3}{*}{ Empat-lajur tak-terbagi } & Per lajur & \\
& 3.00 & -4.00 \\
& 3.25 & -2.00 \\
& 3.50 & 0.00 \\
& 3.75 & 2.00 \\
& 4.00 & 4.00 \\
\hline \multirow{3}{*}{ Dua-lajur tak-terbagi } & Total & \\
& 5.00 & -9.50 \\
& 6.00 & -3.00 \\
& 7.00 & 0.00 \\
& 8.00 & 3.00 \\
& 9.00 & 4.00 \\
& 10.00 & 6.00 \\
& 11.00 & 7.00 \\
\hline
\end{tabular}

Sumber : MKJI (1997)

Faktor penyesuaian kecepatan arus bebas akibat hambatan samping berdasarkan jarak kereb dan penghalang pada trotoar $\left(\mathrm{FFV}_{\mathrm{SF}}\right)$ untuk jalan perkotaan dapat dilihat pada Tabel 9. 
Tabel 9. Faktor Penyesuaian Kecepatan Arus Bebas untuk Hambatan Samping dengan Jarak Kereb Penghalang $\left(\mathrm{FFV}_{\mathrm{SF}}\right)$

\begin{tabular}{|c|c|c|c|c|c|}
\hline \multirow{3}{*}{ Tipe Jalan } & \multirow{3}{*}{$\begin{array}{c}\text { Kelas hambatan } \\
\text { samping } \\
\text { (SFC) }\end{array}$} & \multicolumn{4}{|c|}{ FFV $_{\text {SF }}$} \\
\hline & & \multicolumn{4}{|c|}{ Jarak : Kereb-penghalang $\left(\mathbf{W}_{\mathbf{k}}\right)(\mathbf{m})$} \\
\hline & & $\leq \mathbf{0 , 5 0}$ & 1.00 & 1.50 & $\geq 2,00$ \\
\hline \multirow{5}{*}{$\begin{array}{l}\text { Empat-lajur terbagi } \\
(4 / 2 \mathrm{D})\end{array}$} & Sangat rendah & 1.00 & 1.01 & 1.01 & 1.02 \\
\hline & Rendah & 0.97 & 0.98 & 0.99 & 1.00 \\
\hline & Sedang & 0.93 & 0.95 & 0.97 & 0.99 \\
\hline & Tinggi & 0.87 & 0.90 & 0.93 & 0.96 \\
\hline & Sangat tinggi & 0.81 & 0.85 & 0.88 & 0.92 \\
\hline \multirow{5}{*}{$\begin{array}{c}\text { Empat-lajur tak- } \\
\text { terbagi } \\
(4 / 2 \mathrm{UD})\end{array}$} & Sangat rendah & 1.00 & 1.01 & 1.01 & 1.02 \\
\hline & Rendah & 0.96 & 0.98 & 0.99 & 1.00 \\
\hline & Sedang & 0.91 & 0.93 & 0.96 & 0.98 \\
\hline & Tinggi & 0.84 & 0.87 & 0.90 & 0.94 \\
\hline & Sangat tinggi & 0.77 & 0.81 & 0.85 & 0.90 \\
\hline \multirow{5}{*}{$\begin{array}{c}\text { Dua-lajur tak-terbagi } \\
\text { (2/2 UD) atau } \\
\text { Jalan satu arah }\end{array}$} & Sangat rendah & 0.98 & 0.99 & 0.99 & 1.00 \\
\hline & Rendah & 0.93 & 0.95 & 0.96 & 0.98 \\
\hline & Sedang & 0.87 & 0.89 & 0.92 & 0.95 \\
\hline & Tinggi & 0.78 & 0.81 & 0.84 & 0.88 \\
\hline & Sangat tinggi & 0.68 & 0.72 & 0.77 & 0.82 \\
\hline
\end{tabular}

Sumber : MKJI (1997)

Faktor penyesuaian untuk ukuran kota pada kecepatan arus bebas kendaraan $\left(\mathrm{FFV}_{\mathrm{CS}}\right)$ dapat dilihat pada Tabel 10.

Tabel 10. Faktor Penyesuaian Kecepatan Arus Bebas untuk Ukuran Kota $\left(\mathrm{FFV}_{\mathrm{CS}}\right)$

\begin{tabular}{|c|c|}
\hline Ukuran kota (juta Penduduk) & Faktor penyesuaian untuk ukuran kota \\
\hline$<0,10$ & 0.90 \\
$0,10-0,50$ & 0.93 \\
$0,50-1,00$ & 0.95 \\
$1,00-3,00$ & 1.00 \\
$>3,00$ & 1.03 \\
\hline
\end{tabular}

Sumber : MKJI (1997) 


\section{Kapasitas}

Menurut MKJI (1997) kapasitas didefinisikan sebagai arus lalu lintas maksimum yang melalui suatu titik dan dapat dipertahankan per satuan jam pada kondisi tertentu. Untuk jalan dua lajur arah, kapasitas ditentukan untuk arus dua arah (kombinasi dua arah), tetapi untuk jalan dengan banyak lajur, arus dipisahakan per arah dan kapasitas ditentukan per lajur.

Menurut Buku Standard Desain Geometrik Jalan Perkotaan yang dikeluarkan oleh Dirjen Bina Marga, kapasitas dasar didefinisikan sebagai volume maksimum per jam yang dapat melewati suatu potongan lajur jalan (untuk jalan multi lajur) atau suatu potongan jalan (untuk jalan dua lajur) pada kondisi jalan dan arus lalu lintas ideal.

Kondisi ideal terjadi bila :

- Lebar lajur tidak kurang dari 3,5 m

- Kebebasan lateral tidak kurang dari $1,75 \mathrm{~m}$

- Standard geometrik baik

- Hanya kendaraan ringan (LV) yang menggunakan jalan

- Tidak ada batas kecepatan

Persamaan untuk menentukan kapasitas adalah sebagai berikut :

$\mathrm{C}=\mathrm{C}_{\mathrm{o}} \times \mathrm{FC}_{\mathrm{w}} \times \mathrm{FC}_{\mathrm{SP}} \times \mathrm{FC}_{\mathrm{SF}} \times \mathrm{FC}_{\mathrm{CS}}$

dimana : 


$$
\begin{aligned}
& \text { C = Kapasitas } \\
& \left.\mathrm{C}_{\mathrm{o}} \quad=\text { Kapasitas dasar ( } \mathrm{smp} / \mathrm{jam}\right) \\
& \mathrm{FC}_{\mathrm{w}}=\text { Faktor penyesuaian lebar jalur lalu lintas } \\
& \mathrm{FC}_{\mathrm{SP}}=\text { Faktor penyesuaian pemisah arah } \\
& \mathrm{FC}_{\mathrm{SF}}=\text { Faktor penyesuaian hambatan samping } \\
& \mathrm{FC}_{\mathrm{CS}}=\text { Faktor penyesuaian ukuran kota }
\end{aligned}
$$

Kapasitas dasar $\left(\mathrm{C}_{\mathrm{o}}\right)$ segmen jalan pada kondisi geometrik ditentukan berdasarkan tipe jalan sesuai dengan Tabel 11.

Tabel 11. Kapasitas Dasar $\left(\mathrm{C}_{\mathrm{o}}\right)$ Jalan Perkotaan

\begin{tabular}{|l|c|l|}
\hline \multicolumn{1}{|c|}{ Tipe jalan } & $\begin{array}{c}\text { Kapasitas } \\
\text { dasar } \\
\text { (smp/jam) }\end{array}$ & catatan \\
\hline Empat-lajur terbagi atau Jalan satu-arah & 1650 & Per lajur \\
\hline Empat-lajur tak-terbagi & 1500 & Per lajur \\
\hline Dua-lajur tak-terbagi & 2900 & Total dua arah \\
\hline
\end{tabular}

Sumber : MKJI (1997)

Faktor penyesuaian lebar jalan ditentukan berdasarkan lebar jalur lalu lintas yang dapat dilihat pada Tabel 12 . 
Tabel 12. Faktor Penyesuaian Kapasitas Lebar Jalur Lalu Lintas $\left(\mathrm{FC}_{\mathrm{w}}\right)$

\begin{tabular}{|c|c|c|}
\hline \multirow{2}{*}{ Tipe jalan } & Lebar jalur lalu lintas efektif $\left(W_{c}\right)$ & \multirow{2}{*}{$\mathbf{F C}_{\mathrm{w}}$} \\
\hline & $(\mathbf{m})$ & \\
\hline \multirow{6}{*}{$\begin{array}{c}\text { Empat-lajur terbagi } \\
\text { atau } \\
\text { Jalan satu-arah }\end{array}$} & Per lajur & \\
\hline & 3.00 & 0.92 \\
\hline & 3.25 & 0.96 \\
\hline & 3.50 & 1.00 \\
\hline & 3.75 & 1.04 \\
\hline & 4.00 & 1.08 \\
\hline \multirow{6}{*}{ Empat-lajur tak terbagi } & Per lajur & \\
\hline & 3.00 & 0.91 \\
\hline & 3.25 & 0.95 \\
\hline & 3.50 & 1.00 \\
\hline & 3.75 & 1.05 \\
\hline & 4.00 & 1.09 \\
\hline \multirow{8}{*}{ Dua-lajur tak-terbagi } & Total kedua arah & \\
\hline & 5 & 0.56 \\
\hline & 6 & 0.87 \\
\hline & 7 & 1.00 \\
\hline & 8 & 1.14 \\
\hline & 9 & 1.25 \\
\hline & 10 & 1.29 \\
\hline & 11 & 1.34 \\
\hline
\end{tabular}

Faktor penyesuaian pemisah arah jalan didasarkan pada kondisi dan distribusi arus lalu lintas dari kedua arah jalan atau tipe jalan tanpa pembatas median.

Untuk jalan satu arah atau jalan dengan median faktor koreksi pembagian arah adalah 1,0. Faktor penyesuaian pemisah arah dapat dilihat pada Tabel 13.

Tabel 13. Faktor penyesuaian Pemisah Arah $\left(\mathrm{FC}_{\mathrm{SP}}\right)$

\begin{tabular}{|c|c|c|c|c|c|c|}
\hline \multicolumn{2}{|c|}{ Pemisah arah SP \% - \% } & $\mathbf{5 0}-\mathbf{5 0}$ & $\mathbf{5 5}-\mathbf{4 5}$ & $\mathbf{6 0}-\mathbf{4 0}$ & $\mathbf{6 5}-\mathbf{3 5}$ & $\mathbf{7 0}-\mathbf{3 0}$ \\
\hline \multirow{2}{*}{$\mathrm{FC}_{\mathrm{SP}}$} & Dua-lajur (2/2) & 1.000 & 0.970 & 0.940 & 0.910 & 0.880 \\
\cline { 2 - 7 } & Empat-lajur (4/2) & 1.000 & 0.985 & 0.970 & 0.955 & 0.940 \\
\hline
\end{tabular}

Sumber : MKJI (1997) 
Faktor penyesuaian kapasitas untuk hambatan samping $\left(\mathrm{FC}_{\mathrm{SF}}\right)$ berdasarkan jarak antara kereb dan penghalang pada trotoar $\left(\mathrm{W}_{\mathrm{k}}\right)$, dan kelas hambatan samping (SFC).

Nilai faktor penyesuaian kapasitas untuk pengaruh hambatan samping dan jarak kereb-penghalang $\left(\mathrm{FC}_{\mathrm{SF}}\right)$ untuk jalan perkotaan dengan kereb, dapat dilihat pada Tabel 14.

Tabel 14. Faktor penyesuaian untuk hambatan samping dan jarak kereb-penghalang

$$
\left(\mathrm{FC}_{\mathrm{SF}}\right)
$$

\begin{tabular}{|c|c|c|c|c|c|}
\hline \multirow{3}{*}{ Tipe jalan } & \multirow{3}{*}{$\begin{array}{c}\text { Kelas } \\
\text { hambatan } \\
\text { samping }\end{array}$} & \multicolumn{4}{|c|}{$\begin{array}{c}\text { Faktor penyesuaian untuk hambtan samping dan } \\
\text { jarak kereb-penghalang }\left(\mathrm{FC}_{\mathrm{SF}}\right)\end{array}$} \\
\hline & & \multicolumn{4}{|c|}{ Jarak : kereb-penghalang $\left(\mathrm{W}_{\mathrm{k}}\right)$} \\
\hline & & $\leq \mathbf{0 , 5 0}$ & 1.0 & 1.5 & $\geq 2,0$ \\
\hline \multirow{5}{*}{$4 / 2 \mathrm{D}$} & VL & 0.95 & 0.97 & 0.99 & 1.01 \\
\hline & $\mathrm{L}$ & 0.94 & 0.86 & 0.98 & 1.00 \\
\hline & $\mathrm{M}$ & 0.91 & 0.93 & 0.95 & 0.98 \\
\hline & $\mathrm{H}$ & 0.86 & 0.89 & 0.92 & 0.95 \\
\hline & VH & 0.81 & 0.85 & 0.88 & 0.92 \\
\hline \multirow{5}{*}{$4 / 2 \mathrm{UD}$} & VL & 0.95 & 0.97 & 0.99 & 1.01 \\
\hline & $\mathrm{L}$ & 0.93 & 0.95 & 0.97 & 1.00 \\
\hline & M & 0.90 & 0.92 & 0.95 & 0.97 \\
\hline & $\mathrm{H}$ & 0.84 & 0.87 & 0.90 & 0.93 \\
\hline & $\mathrm{VH}$ & 0.77 & 0.81 & 0.85 & 0.90 \\
\hline \multirow{5}{*}{$4 / 2 \mathrm{UD}$} & VL & 0.93 & 0.95 & 0.97 & 0.99 \\
\hline & $\mathrm{L}$ & 0.9 & 0.92 & 0.95 & 0.97 \\
\hline & M & 0.86 & 0.88 & 0.91 & 0.94 \\
\hline & $\mathrm{H}$ & 0.78 & 0.81 & 0.84 & 0.88 \\
\hline & $\mathrm{VH}$ & 0.68 & 0.72 & 0.77 & 0.82 \\
\hline
\end{tabular}

Sumber : MKJI (1997) 
Faktor penyesuaian ukuran kota didasarkan pada jumlah penduduk, dapat dilihat pada Tabel 15 .

Tabel 15. Faktor Penyesuaian Kapasitas untuk Ukuran Kota $\left(\mathrm{FC}_{\mathrm{CS}}\right)$

\begin{tabular}{|c|c|}
\hline $\begin{array}{c}\text { Ukuran kota } \\
\text { (Juta penduduk) }\end{array}$ & Faktor penyesuaian untuk ukuran kota \\
\hline$<1,0$ & 0.86 \\
\hline $0,10-0,50$ & 0.90 \\
\hline $0,50-1,00$ & 0.94 \\
\hline $1,00-3,00$ & 1.00 \\
\hline$>3,00$ & 1.04 \\
\hline
\end{tabular}

Sumber : MKJI (1997)

\section{Derajat Kejenuhan (DS)}

Dejarat kejenuhan (DS) menurut MKJI (1997) yakni sebagai rasio jalan terhadap kapasitas, yang digunakan sebagai faktor utama dalam penentuan tingkat kinerja simpang dan segmen jalan. Nilai DS menunjukkan apakah segmen jalan tersebut mempunyai masalah kapasitas atau tidak. Persamaan dasar untuk menentukan derajat kejenuhan atau degree of saturation (DS) adalah sebagai berikut :

$$
D S=\frac{Q}{C}
$$

dimana :

$$
\begin{array}{ll}
\mathrm{DS} & =\text { Derajat kejenuhan } \\
\mathrm{Q} & =\text { Arus lalu lintas }(\mathrm{smp} / \mathrm{jam}) \\
\mathrm{C} & =\text { Kapasitas }(\mathrm{smp} / \mathrm{jam})
\end{array}
$$

Derajat kejenuhan digunakan untuk menganalisis perilaku lalu lintas. 


\section{Kecepatan dan Waktu Tempuh}

MKJI (1997) menggunakan kecepatan dan waktu tempuh sebagai ukuran utama kinerja segmen jalan, karena mudah dimengerti dan diukur, dan merupakan masukan yang penting untuk biaya pemakai jalan dalam analisis ekonomi.

Persamaan untuk menghasilkan waktu tempuh rata-rata (TT) adalah :

$$
T T=\frac{L}{V_{L V}}
$$

dimana :

$$
\begin{array}{ll}
\mathrm{TT} & =\text { Waktu tempuh rata-rata }(\text { jam }) \\
\mathrm{L} & =\text { Panjang Segmen }(\mathrm{km}) \\
\mathrm{V}_{\mathrm{LV}} & =\text { Kecepatan Kendaraan ringan }
\end{array}
$$

Kecepatan Kendaraan ringan ditentukan melalui grafik pada Gambar 1.

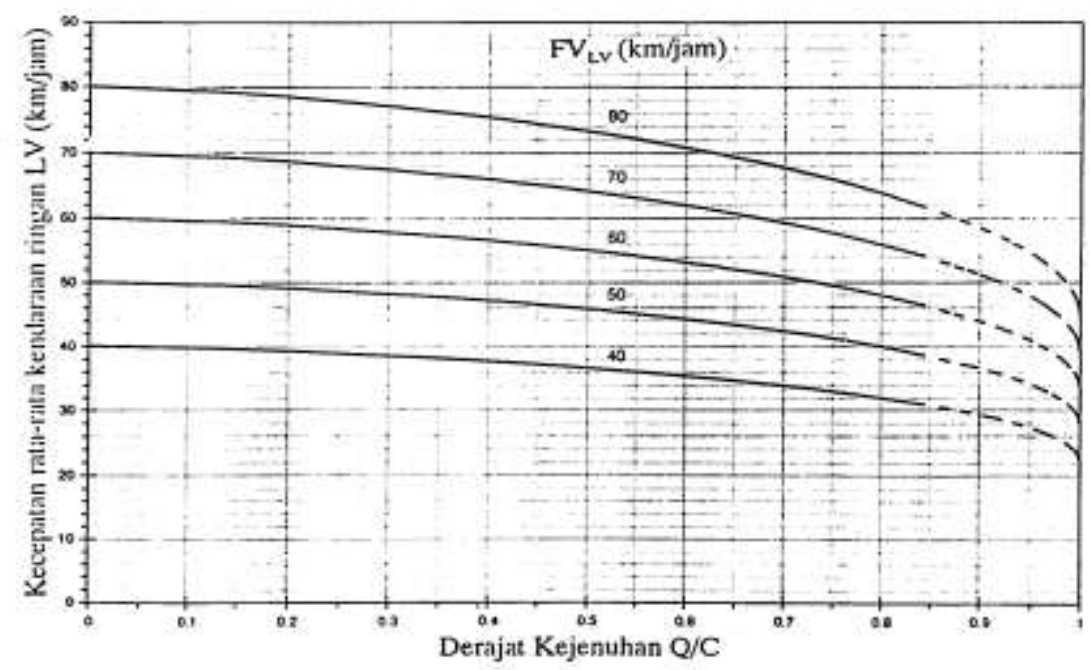

Gambar 1. Grafik Kecepatan sebagai fungsi dari DS untuk jalan banyak lajur dan satu arah 


\section{Tingkat Pelayanan}

Tingkat pelayanan jalan menurut Hendarto (2001) adalah suatu ukuran kualitas perjalanan dalam arti luas menggambarkan kondisi lalu lintas yang mungkin timbul pada suatu jalan akibat dari volume lalu lintas.

Lebar dan jumlah lajur yang dibutuhkan tidak dapat direncanankan dengan baik walaupun VJP/LHR telah ditentukan. Hal ini disebabkan oleh karena tingkat kenyamanan dan keamanan yang akan diberikan oleh jalan rencana belum ditentukan. Kebebasan bergerak yang dirakan oleh pengemudi akan lebih baik pada jalan-jalan yang kebebasan samping yang memadai, tetapi hal tersebut saja menuntut daerah manfaat jalan yang lebih lebar pula.

Pada suatu kenadaan dengan volume lalu lintas yang rendah, pengemudi akan merasa nyaman mengendarai kendaraaan dibanding jika pengemudi berada pada daerah tersebut dengan volume lalu lintas yang besar. Kenyamanan akan berkurang sebanding dengan bertambahnya volume lalu lintas. Dengan perkataan lain rasa nyaman dan volume lalu lintas tersebut berbanding terbalik. Tetapi kenyamanan dari kondisi arus lalu lintas yang ada tidak cukup hanya digambarkan dengan volume lalu lintas tanpa disertai data kapasitas jalan dan kecepatan pada jalan tersebut.

Untuk menentukan tingkat pelayanan jalan ada dua faktor utama yang harus diperhatikan yaitu :

1. Kecepatan perjalanan yang menunjukkan keadaan umum di jalan.

2. Perbandingan antara volume terhadap kapasitas (rasio V/C) yang mana menunjukkan kepadatan lalu lintas dan kebebasan beregerak bagi kendaraan. 
Secara umum tingkat pelayanan dibedakan sebagai berikut :

1. Tingkat Pelayanan A : Kondisi arus lalu lintas bebas antara satu kendaraan dengan kendaraan lainnya, besarnya kecepatan sepenuhnya ditentukan oleh keinginan pengemudi dan sesuai dengan batas kecepatan yang ditentukan.

2. Tingkat Pelayanan B : Kondisi arus lalu lintas stabil, kecepatan operasi mulai dibatasi oleh kendaraan lainnya dan mulai dirasakan hambatan oleh kendaraan sekitarnya.

3. Tingkat Pelayanan $\mathrm{C}$ : Kondisi arus lalu lintas masih dalam batas stabil, kecepatan operasi mulai dibatasi dan hambatan dari kendaraan lain semakin besar.

4. Tingkat Pelayanan D : Kondisi arus lalu lintas mendekati tidak stabil, kecepatan operasi menurun relatif cepat akibat hambatan yang timbul dan kebebasan bergerak relatif kecil.

5. Tingkat Pelayanan E : Volume lalu lintas sudah mendekati kapasitas ruas jalan, kecepatan besarnya sekitar lebih rendah dari $40 \mathrm{~km} / \mathrm{jam}$, pergerakan lalu lintas kadang terhambat.

6. Tingkat pelayanan $\mathrm{F}$ : Kondisi arus lalu lintas berada dalam keadaan dipaksakan (forced-flow), kecepatan relatif rendah, arus lalu lintas sering terhenti sehingga menimbulkan antrian yang panjang.

Pada tabel 16 menunjukkan tingkat pelayanan berdasarkan kecepatan dan tingkat kejenuhan serta pada tabel 17 menunjukkan ingkat pelayanan berdasarkan kecepatan rata-rata. 
Tabel 16. Tingkat pelayanan Berdasarkan Kecepatan Bebas dan Tingkat Kejenuhan Lalu Lintas

\begin{tabular}{|c|c|c|}
\hline $\begin{array}{c}\text { Tingkat } \\
\text { Pelayanan }\end{array}$ & Kecepatan Bebas & Tingkat Kejenuhan \\
\hline A & $\geq 90$ & $\leq 0,35$ \\
\hline B & $\geq 70$ & $\leq 0,54$ \\
\hline C & $\geq 50$ & $\leq 0,77$ \\
\hline D & $\geq 40$ & $\leq 0,93$ \\
\hline E & $\geq 33$ & $\leq 1,00$ \\
\hline F & $<33$ & $>1,00$ \\
\hline
\end{tabular}

Sumber : Ofyar Z. Tamin, Analisis Dampak Lalu Lintas (1998)

Tabel 17. Tingkat Pelayanan Berdasarkan Kecepatan Perjalanan Rata-Rata

\begin{tabular}{|l|c|c|c|}
\hline Kelas Arteri & I & II & III \\
\hline Kecepatan (km/jam) & $\mathbf{7 2}$ - 56 & $\mathbf{5 6}$ - 48 & $\mathbf{5 6}$ - 40 \\
\hline Tingkat Pelayanan & \multicolumn{3}{|c|}{ Kecepatan Perjalanan Rata-rata } \\
(km/jam) \\
\hline A & $\geq 56$ & $\geq 48$ & $\geq 40$ \\
\hline B & $\geq 45$ & $\geq 38$ & $\geq 31$ \\
\hline C & $\geq 35$ & $\geq 29$ & $\geq 21$ \\
\hline D & $\geq 28$ & $\geq 23$ & $\geq 15$ \\
\hline E & $\geq 21$ & $\geq 16$ & $\geq 11$ \\
\hline F & $\geq 21$ & $\geq 16$ & $\geq 11$ \\
\hline
\end{tabular}

Sumber : Ofyar Z Tamin, Analisis Dampak Lalu Lintas (1998) 
Tabel 18. Karakteristik Tingkat Pelayanan

\begin{tabular}{|c|l|c|}
\hline $\begin{array}{c}\text { Tingkat } \\
\text { Pelayanan }\end{array}$ & \multicolumn{1}{|c|}{ Karakteristik } & $\begin{array}{c}\text { Batas } \\
\text { Lingkup } \\
\text { ( V / C })\end{array}$ \\
\hline A & $\begin{array}{l}\text { Kondisi arus bebas dengan kecepatan tinggi pengemudi } \\
\text { dapat memilih kecepatan yang diinginkan tanpa } \\
\text { hambatan }\end{array}$ & $0,00-0,19$ \\
\hline B & $\begin{array}{l}\text { Kondisi arus stabil, tetapi kecepatan operasi } \\
\text { mulai dibatasi oleh kondisi lalu lintas. } \\
\text { Pengemudi dibatasi dalam memilih kecepatan }\end{array}$ & $0,20-0,44$ \\
\hline C & $\begin{array}{l}\text { Kondisi arus stabil, tetapi kecepatan operasi dan } \\
\text { gerak kendaraan dipengaruhi besar volume lalu lintas. } \\
\text { Pengemudi dibatasi dalam memilih kecepatan }\end{array}$ & $0,45-0,74$ \\
\hline D & $\begin{array}{l}\text { Kondisi arus lalu lintas tidak stabil, kecepatan masih } \\
\text { dikendalikan, V/C masih dapat ditolerir. }\end{array}$ & $0,75-0,84$ \\
\hline E & $\begin{array}{l}\text { Volume lalu lintas mendekati/berada pada kapasitas. } \\
\text { Arus tidak stabil, kecepatan kadang berhenti. }\end{array}$ & $0,85-1,00$ \\
\hline F & $\begin{array}{l}\text { Kondisi arus lalu lintas dipaksakan atau arus macet, } \\
\text { kecepatan rendah, arus lalu lintas rendah. }\end{array}$ & 1.00 \\
\hline
\end{tabular}

Sumber : Edward K Morlok, Pengantar Teknik \& Perencanaan Transportasi (1991)

Dari keenam jenis tingkat pelayanan di atas maka yang memenuhi syarat jalan yang diinginkan adalah tingkat pelayanan $\mathrm{A}, \mathrm{B}, \mathrm{C}$, dan $\mathrm{D}$ dimana rasio $\mathrm{V} / \mathrm{C}<1$. Pada tingkat pelayanan E dan F, dimana volume lalu lintas telah melebihi kapasitas jalan $\mathrm{V} / \mathrm{C} \geq 1$, sehingga dalam keadaan ini menyebabkan terjadinya penurunan kualitas pelayanan. 


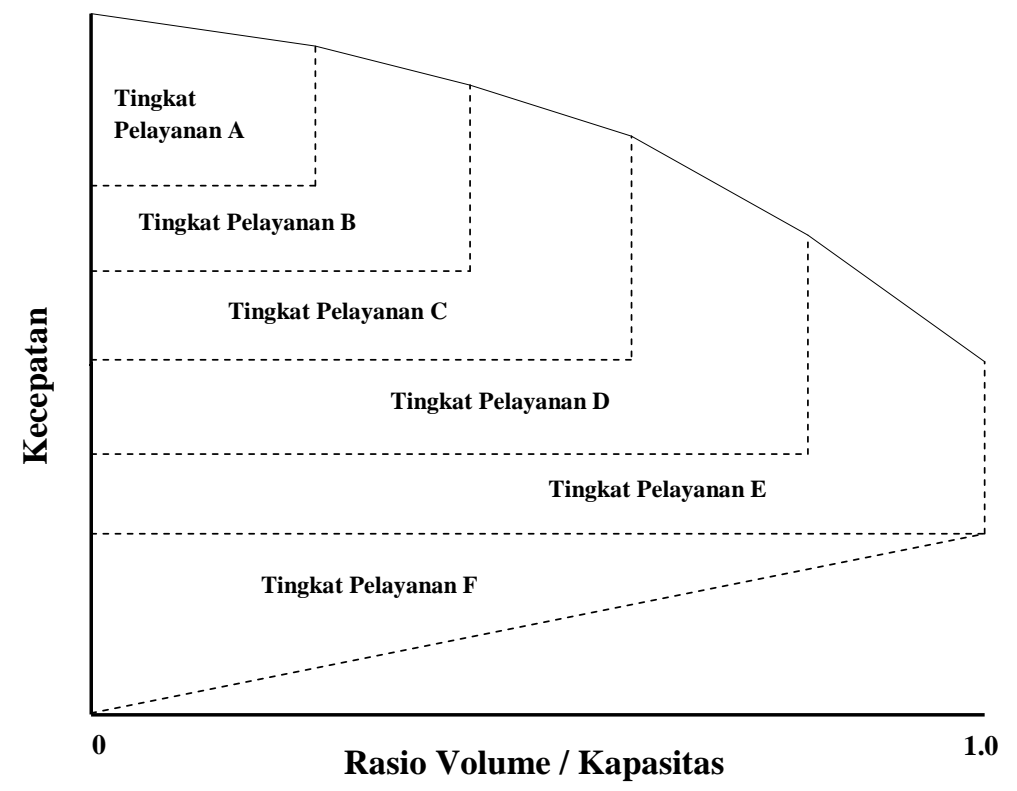

Gambar 2. Hubungan Antara Kecepatan, Tingkat Pelayanan dan Rasio Volume Terhadap Kapasitas untuk Jalan

(Sumber : E. K. Morlock. 1991. Pengantar Teknik dan Perencanaan Transportasi) 


\section{Pertumbuhan Lalu Lintas}

Menurut Abubakar (1999), Pertumbuhan lalu lintas normal merupakan peningkatan volume lalu lintas yang ada karena meningkatnya jumlah kendaraan yang digunakan dan karena perubahan dalam jumlah penggunaan kendaraan (kilometer).

Pertumbuhan volume lalu lintas tahunan merupakan kombinasi dari 2 buah faktor dasar utama yaitu :

\section{Peningkatan Jumlah Kendaraan Bermotor}

Peningkatan jumlah kendaraan bermotor di jalan dapat dianalisis dari jumlah kendaraan yang terdaftar. Peningkatan ini disebabkan oleh :

- Meningkatnya jumlah penduduk.

- Meningkatnya tingkat pendapatan masyarakat yang memungkinkan lebih banyak kendaraan yang dapat dibeli. Sejalan perkembangan negara, maka proporsi dari berbagai jenis kendaraan akan berubah. Meningkatnya pendapatan masyarakat berarti juga bahwa sepada motor yang semula dimiliki akan digantikan dengan mobil.

- Pembangunan umum negara berarti makin banyak bisnis, meningkatnya kebutuhan untuk mengangkut barang dan oleh karena itu timbul tekanan untuk meningkatkan jalan.

- Peningkatan jalan berarti bahwa truk dengan berat 20 - 40 ton dapat digunakan sebagai pengganti truk berbobot 6 -10 ton. Prasarana jalan yang lebih baik akan 
mendorong digunakannya angkutan jalan dimana sebelumya digunakan angkutan air atau udara.

\section{Variasi Jarak Perjalanan}

Variasi jarak tempuh kendaraan selama tahun tertentu dapat dihitung dari data penjualan bahan bakar bensin dan solar ataupun dengan melakukan penelitian terhadap penggunaan kendaraan. Dengan berkembangnya ekonomi negara, pola kendaraan akan berubah demikian juga kebutuhan akan angkutan.

Hal ini tercermin dari nilai kilometer perjalanan yang ditempuh oleh kendaraan selama setahun. Dengan meningkatnya ekonomi masyarakat, akan merubah cara hidupnya, dalam hal ini termasuk pula pola perjalanan. Khususnya mereka akan menggunakan uang untuk aktivitas yang menyenangkan, sehingga pola perjalanan mereka juga berubah.

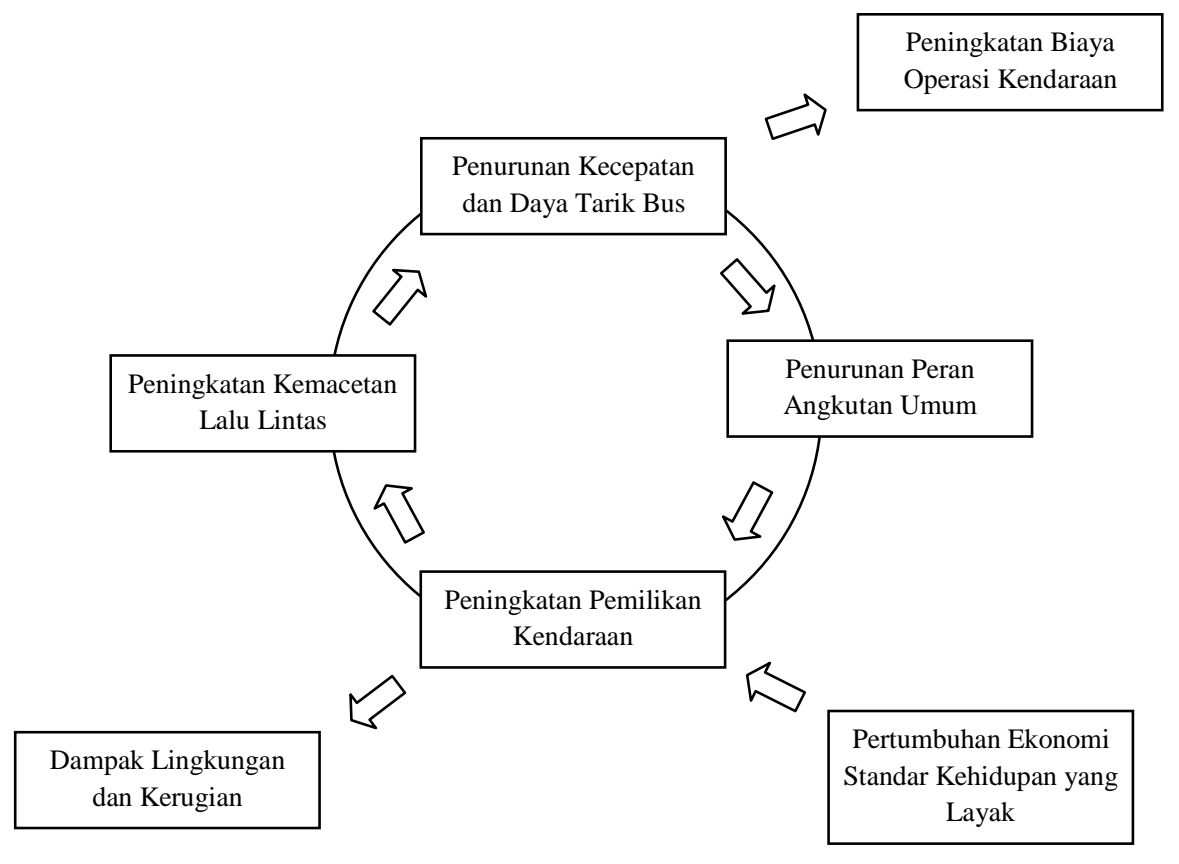

Gambar 3. Siklus Perubahan Pola Perjalanan. 
Pertumbuhan volume lalu lintas pada suatu jalan raya juga tergantung pada beberapa faktor yang berhubungan dengan kondisi daerah setempat. Besaran ini bervariasi, menurut waktu dapat dikelompokkan menjadi 3 bagian utama yaitu :

\section{a. Perubahan Akibat Pertumbuhan Lalu Lintas}

- Pertumbuhan normal, yaitu naiknya jumlah kendaraan yang berada di jalan atau naiknya jumlah perjalanan (trip).

- Differted Traffic, yaitu lalu lintas yang mengubah rute perjalanan karena alasan tertentu.

- Converte Traffic, yaitu lalu lintas karena ada angkutan yang sebelumnya tidak melalui jalur tersebut sekarang melewatinya.

- Generated Traffic, yaitu lalu lintas yang ditimbulkan oleh adanya pembangunan atau perbaikan jalan.

\section{b. Variasi Berkala}

Sifat yang penting untuk diselidiki dari variasi berkala adalah apakah kejadiannya secara beraturan, karena variasi yang beraturan dapat dipakai untuk membantu meramalkan volume lalu lintas diwaktu yang lain. Dalam pergerakan lalu lintas variasi berkala dibedakan atas 3 variasi yaitu :

- Variasi Bulanan, yaitu dalam jangka waktu 1 tahun mungkin tepat disebut variasi akibat musim karena ternyata variasi ini lebih tergantung pada keadaan musim dari pada bulannya. Variasi bulanan tergantung pada keadaan musim 
dimana pada bulan April sampai Oktober (musim kemarau) terjadi peningkatan volume lalu lintas dan pada bulan Oktober sampai April (musim hujan) volume lalu lintas mengalami penurunan.

- Variasi Harian, yaitu dalam seminggu sangat dipengaruhi oleh kegiatan manusia yang umumnya mempunyai jadwal kegiatan dalam seminggu. Variasi harian ini mempunyai kencenderungan untuk tetap dan konstan.

- Variasi Menurut Jam, yaitu dalam jangka waktu sehari normal tertentu, variasi menurut jam konstan dan biasanya terlihat jam sibuk pada pagi dan sore.

\section{c. Variasi Tak berkala}

Variasi ini tak berulangan secara beraturan dan dapat disebabkan oleh kejadian yang diluar dugaan seperti adanya bencana alam, hari raya, kunjungan pembesar dan sebagainya.

Ada 3 jenis data historis yang dapat dianalisis untuk memperkirakan pertumbuhan lalu lintas :

- Pencacahan volume lalu lintas, yang memberikan pertumbuhan volume lalu lintas pada jalan-jalan tertentu.

- Data kendaraan yang terdaftar, baik ditingkat nasional, regional dan lokal yang memberikan jumlah kendaraan yang ada disuatu daerah.

- Data statistik penjualan dan komsumsi bahan bakar di tingkat nasional, regional dan lokal yang dapat digunakan untuk menghitung total perjalanan dalam kendaraan-kilometer. 


\section{E. Peramalan Lalu Lintas}

Menurut Abubakar (1999), Peramalan lalu lintas yang sederhana dilakukan dengan melakukan penaksiran arus lalu lintas berdasarkan kecenderungan data historis, seperti ditunjukkan dalam gambar 4.

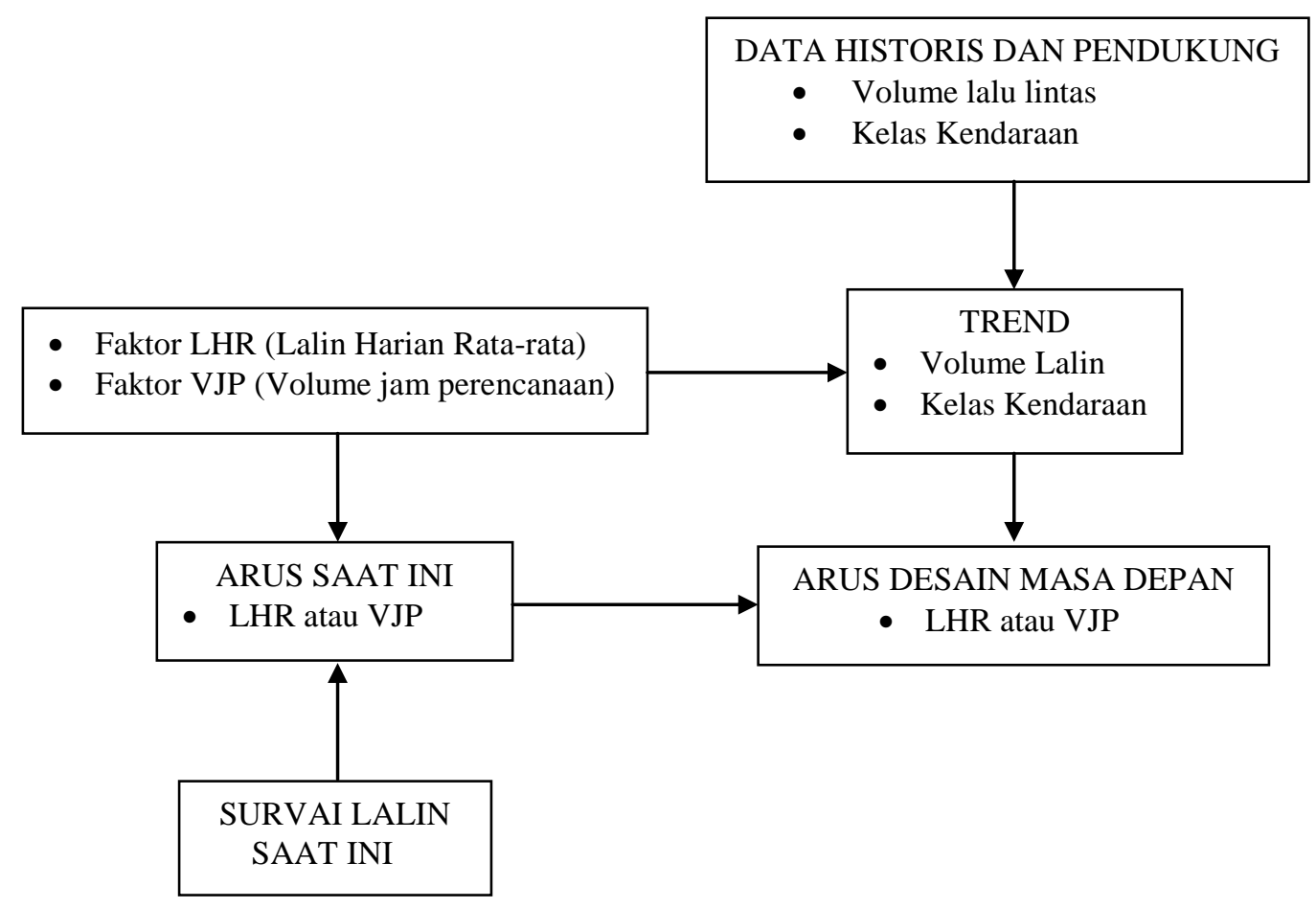

Gambar 4. Peramalan Arus Lalu Lintas

(Sumber : Iskandar Abubakar, Dkk. 1999. Rekayasa Lalu Lintas)

\section{Analisis Arus Lalu Lintas}

a. Lalu Lintas Harian Rata-rata (LHR)

Lalu lintas harian rata-rata adalah volume lalu lintas rata dalam satu hari. Untuk dapat menghitung LHRT haruslah tersedia data jumlah kendaraan yang terus menerus selama satu tahun penuh. Mengingat akan biaya yang diperlukan untuk membandingkan dengan ketelitian yang dicapai serta tak semua tempat di Indonesia 
mempunyai volume lalu lintas selama 1 tahun, maka untuk kondisi tersebut dapat pula dipergunakan Lalu Lintas Harian Rata-Rata (LHR). LHR adalah hasil bagi pengamatan.

b. Volume Jam Perencanaan (VJP)

Arus lalu lintas bervariasi dari jam ke jam berikutnya dalam satu hari, maka sangat cocoklah jika volume lalu lintas dalam 1 jam dipergunakan untuk perencanaan. Volume dalam 1 jam yang dipakai untuk perencanaan dinamakan volume jam perencanaan (VJP).

\section{Tahun Perencanaan}

Jalan baru mempunyai umur konstruksi antara 20 - 40 tahun. Jalan merupakan investasi yang mahal dan mempunyai konsekwensi sosial yang besar. Peramalan lalu lintas untuk keperluan jalan baru biasanya dilakukan untuk selama 20 tahun dimasa datang dan kadang-kadang lebih. Strategi perencanaan perkotaan bahkan didasarkan pada periode yang lebih panjang lagi. Akan tetapi peramalan untuk rencana perekayasaan dan manajemen lalu lintas merupakan peramalan jangka pendek yang biasanya berkisar antara 0 - 5 dan maksimum 10 tahun

\section{Pertumbuhan Lalu Lintas Normal dan Kecenderungan}

Ada 3 jenis data historis yang dapat dianalisis untuk memperkirakan pertumbuhan lalu lintas :

- Pencacahan volume lalu lintas, yang memberikan pertumbuhan volume lalu lintas pada jalan-jalan tertentu. 
- Data kendaraan yang terdaftar baik di tingkat nasional, regional, dan lokal yang memberikan jumlah kendaraan yang ada disuatu daerah.

- Data statistik penjualan dan komsumsi bahan bakar di tingkat nasional regional dan lokal yang dapat digunakan untuk menghitung total perjalanan dalam kendaraan-kilometer. Analisis didasarkan pada persentase dan tingkat komsumsi bahan bakar dari berbagai jenis kendaraan sesuai dengan data kendaraan yang terdaftar.

\section{Peramalan Kecenderungan di masa datang}

Apabila kecenderungan telah ditetapkan dari data historis, maka kecenderungan tersebut dapat diekstrolasikan untuk memperkirakan kondisi masa datang. Proses ini memerlukan sedikit data, dan peramalan jangka pendek yang akurat dapat disiapkan dengan cepat tanpa survei yang mahal. Akan tetapi makin apanjang periode peramalan, maka makin besar ketidakpastian tentang nilai yang diperkirakan. Hal ini dikarenakan tidak dapat ditentukan alasan yang mendasar untuk melakukan perjalanan.

Rencana perekayasaan dan manajemen lalu lintas, seperti pemasangan sinyal lalu lintas, tidak memerlukan biaya yang tinggi, dan hanya memerlukan peramalan jangka pendek. Akan tetapi, pemebangunan jalan baru adalah mahal dan mempunyai implikasi jangka panjang, analisis pertumbuhan lalu lintas yang lebih akurat (yang memerlukan waktu serta biaya yang mahal) perlu dilakukan, dana hal ini dapat diterima mengingat biaya dan keuntungan yang ada. 
F. Kerangka Pikir

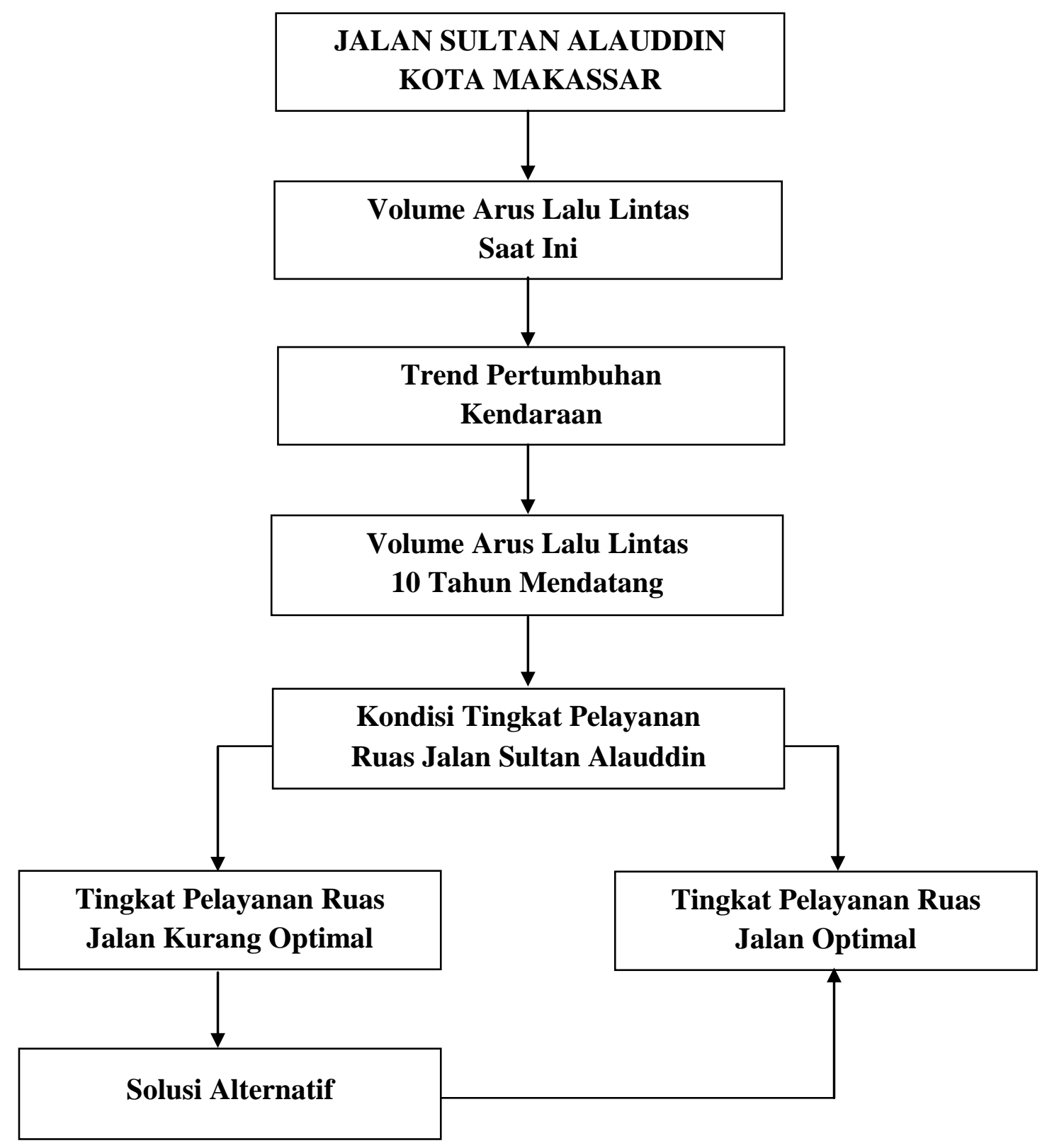

Gambar 5. Skema Kerangka Pikir 


\section{BAB III}

\section{METODE PENELITIAN}

\section{A. Bentuk, Waktu dan Lokasi Penelitian}

1. Bentuk peneltian yang akan digunakan adalah survey lalu lintas.

2. Waktu penelitian dilakukan selama 4 hari yaitu pada setiap hari Senin pada pukul 07.00 - 09.00 dan 16.00 - 19.00. Penentuan waktu survey didasarkan dari penelitian yang sudah dilakukan sebelumnya dan ditarik kesimpulan bahwa pada hari dan jam tersebut adalah waktu jam puncak arus lalu lintas pada ruas jalan tersebut. Waktu penelitian dapat dilihat pada Tabel 19.

Tabel 19. Waktu Penelitian

\begin{tabular}{|c|c|c|c|}
\hline \multirow{2}{*}{ No. } & Hari / Tanggal & \multicolumn{2}{|c|}{ Jam Penelitian } \\
\cline { 2 - 4 } & Penelitian & Pagi & Sore \\
\hline 1. & Senin / 03 Maret 2008 & $06.00-09.00$ & $16.00-19.00$ \\
\hline 2. & Senin / 10 Maret 2008 & $06.00-09.00$ & $16.00-19.00$ \\
\hline 3. & Senin / 17 Maret 2008 & $06.00-09.00$ & $16.00-19.00$ \\
\hline 4 & Senin / 24 Maret 2008 & $06.00-09.00$ & $16.00-19.00$ \\
\hline
\end{tabular}

3. Lokasi pengambilan data/survey arus lalu lintas terletak di ruas Jalan Sultan Alauddin Kota Makassar dapat dilihat pada gambar 6. 


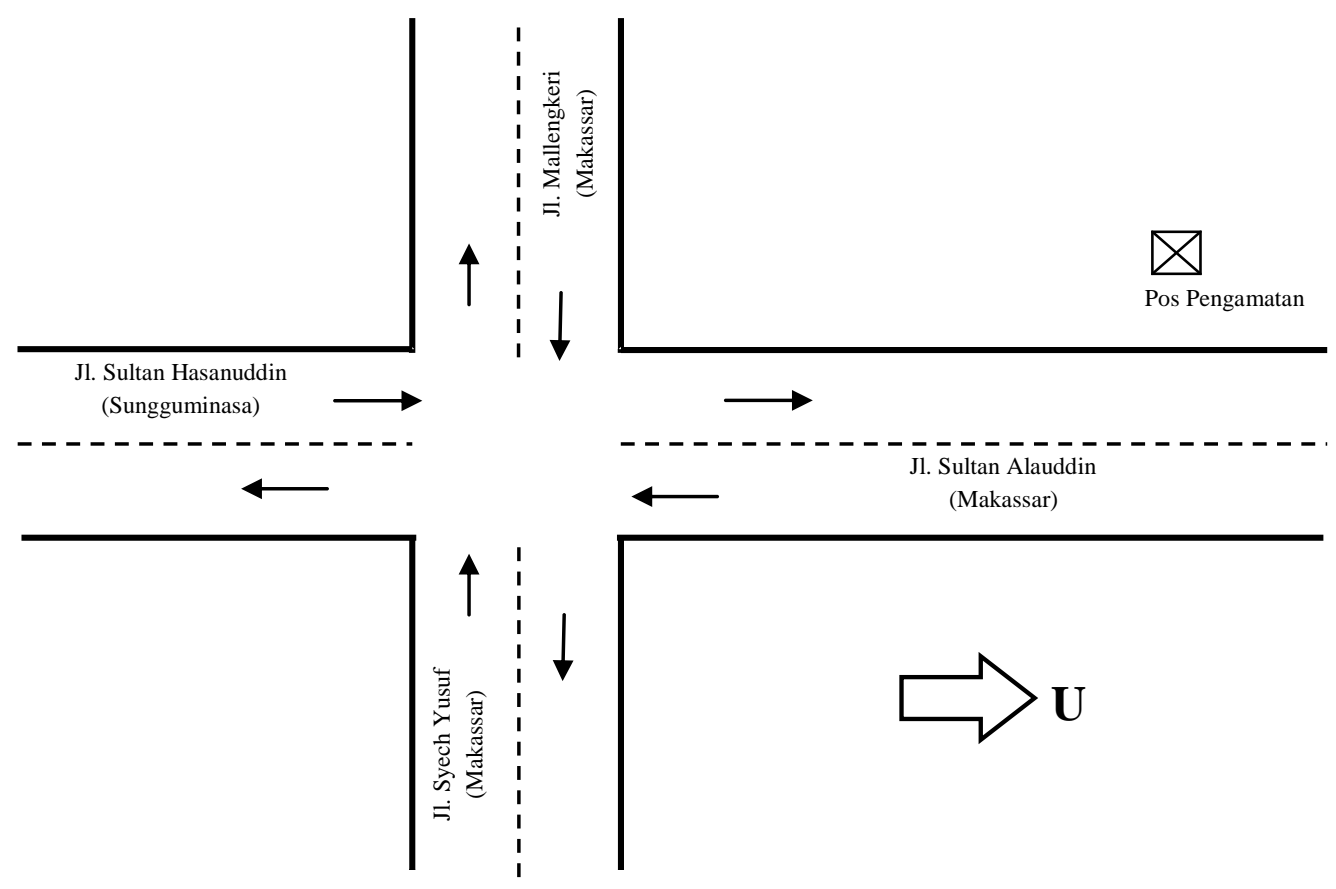

Gambar 6. Lokasi Penelitian

\section{B. Definisi Variabel Operasional}

\section{Volume lalu lintas}

Merupakan jumlah kendaraan yang melalui titik pada jalan per satuan waktu, dinyatakan dalam kend/jam $\left(\mathrm{Q}_{\text {kend }}\right)$, smp/jam $\left(\mathrm{Q}_{\text {smp }}\right)$, LHRT ( $\left.\mathrm{Q}_{\mathrm{LHRT}}\right)$.

\section{Kecepatan kendaraan}

Merupakan perbandingan antara jarak yang ditempuh dengan waktu yang diperlukan untuk menempuh jarak tarsebut, dinyatakan dalam km/jam.

\section{Kapasitas}

Merupakan arus lalu lintas maksimum yang melalui suatu titik dan dapat dipertahankan per satuan waktu (jam) pada kondisi tertentu. Untuk jalan dua lajur 
arah, kapasitas ditentukan untuk arus dua arah (kombinasi dua arah), tetapi untuk jalan dengan banyak lajur, arus dipisahakan per arah dan kapasitas ditentukan per lajur.

\section{Hambatan samping}

Hambatan samping, banyaknya kegiatan hambatan samping jalan di Indonesia sering menimbulkan konflik, hingga menghambat arus lalu lintas, misalkan :

a. Pejalan kaki

b. Angkutan umum dan kendaraan yang berhenti

c. Kendaraan lambat (Becak, Sepeda, Gerobak dan lain-lain)

d. Kendaraan masuk dan keluar dari lahan samping jalan

\section{Kondisi geometrik Jalan}

Merupakan kondisi yang digambarkan dalam bentuk sketsa yang memberikan informasi lebar ruas jalan, lebar bahu, lebar trotoar, median, tipe jalan (jalan terbagi atau jalan tak terbagi), lebar daerah manfaat jalan (damaja), lebar daerah milik jalan (damija) serta lebar daerah pengawasan jalan (dawasja).

\section{Tingkat Pelayanan}

Merupakan kondisi lalu lintas yang mungkin timbul pada suatu jalan akibat dari berbagai volume pergerakan, kapasitas dan kecepatan pergerakan.

\section{Pemisah arah}

Merupakan distribusi arah lalu lintas pada jalan dua-arah (biasanya dinyatakan dalam persentase dari arus total pada masing arah, misalnya 60/40) 


\section{Variabel Penelitian}

Adapun yang menjadi obyek dari penelitian ini adalah :

1. Kondisi Arus lalu Lintas

a. Data lalu lintas yang dibagi dalam tipe kendaraan, yaitu :

1) Kendaraan ringan atau Light Vehicles (LV), meliputi angkutan kota, mobil pribadi, oplet, taksi dan pick up.

2) Kendaraan berat atau Heavy Vehicles (HV), meliputi truk roda 4, truk roda 6, bus standar dan damri.

3) Sepeda motor atau Motorcycles (MC), meliputi semua sepada motor.

4) Kendaraan tak bermotor atau Unmotorrised (UM), meliputi becak, sepeda, andong, gerobak dan lain-lain.

2. Hambatan Samping

3. Kondisi Geometrik Jalan

4. Kecepatan Kendaraan.

\section{Jenis dan Teknik Pengumpulan Data.}

Pengumpulan data lapangan dilakukan dengan cara seteliti mungkin agar diperoleh data yang akurat dan memenuhi. Data-data yang diukur dalam penelitian adalah sebagai berikut :

\section{Data Geometrik Jalan}

Data geometrik yang sesuai untuk segmen yang diamati yaitu : 
- Lebar jalur lalu intas pada kedua sisi/arah.

- Jika terdapat kereb atau bahu pada masing-masing sisi.

- Jarak rata-rata dari kereb ke penghalang pada trotoar seperti pepohonan, tiang lampu dan lain-lain.

- Lebar bahu efektif (jika hanya mempunyai bahu pada satu sisi, lebar bahu ratarata adalah sama dengan setengah lebar bahu tersebut).

- Lebar daerah manfaat jalan (damaja), lebar daerah milik jalan (damija) dan lebar pengawasan jalan (dawasja).

\section{Data Lalu Lintas}

Data diperoleh dengan pengamatan langsung terhadap arus lalu lintas yang meliputi :

a. Survey Volume lalu lintas, survey dilakukan dengan cara menghitung langsung jumlah kendaraan yang melewati titik pengamatan dengan menggunakan Hand Tally Counter atau lembar formulir pencatatan yang dilakukan oleh 6 orang, dimana setiap orang akan menghitung tiap jenis kendaraan berdasarkan klasifikasinya.

b. Survey kecepatan kendaraan, survey dilakukan dengan cara menghitung waktu tempuh kendaraan yang melewati titik pengamatan dengan jarak tertentu dengan menggunakan alat bantu stopwatch dan meteran. Survey dilakukan oleh 2 orang pada satu lajur.

c. Survey hambatan samping, survey ini dilakukan dengan menghitung langsung kejadian per jam per 200 meter atau per segmen jalan pada lajur yang diamati. 
Adapun prosedur untuk menentukan segmen jalan menurut MKJI 1997 adalah :

- Diantara dan tidak dipengaruhi oleh simpang besinyal atau tak bersinyal utama.

- Mempunyai karakteristik yang hampir sama disepanjang jalan.

Tipe kejadian menurut MKJI (1997) digolongkan sebagai berikut :

- Jumlah pejalan kaki yang berjalan atau menyebrang sepanjang segmen jalan.

- Jumlah kendaraan berhenti atau parkir.

- Jumlah kendaraan bermotor yang masuk dan keluar dari lahan samping jalan.

- Arus kendaraan yang bergerak lambat, yaitu sepeda, becak, pedati, traktor dan sebagainya.

Survey dilakukan oleh 2 orang pada lajur jalan per 200 meter, dimana setiap orang menghitung semua tipe kejadian yang ada. 


\section{E. Teknik Analisis Data}

Data yang diperoleh dari hasil pengamatan dan survey arus lalu lintas dilapangan akan dianalisis dengan menggunakan program :

\section{Program analisis lalu lintas untuk ruas jalan perkotaan}

Program analisis lalu lintas untuk ruas jalan perkotaan berdasarkan Manual Kapasitas Jalan Indonesia (MKJI 1997) yang digunakan untuk menghitung kapasitas ruas jalan. Program ini dibuat oleh Dr.-Ing. Ir. Ahmad Munawar, M.Sc.

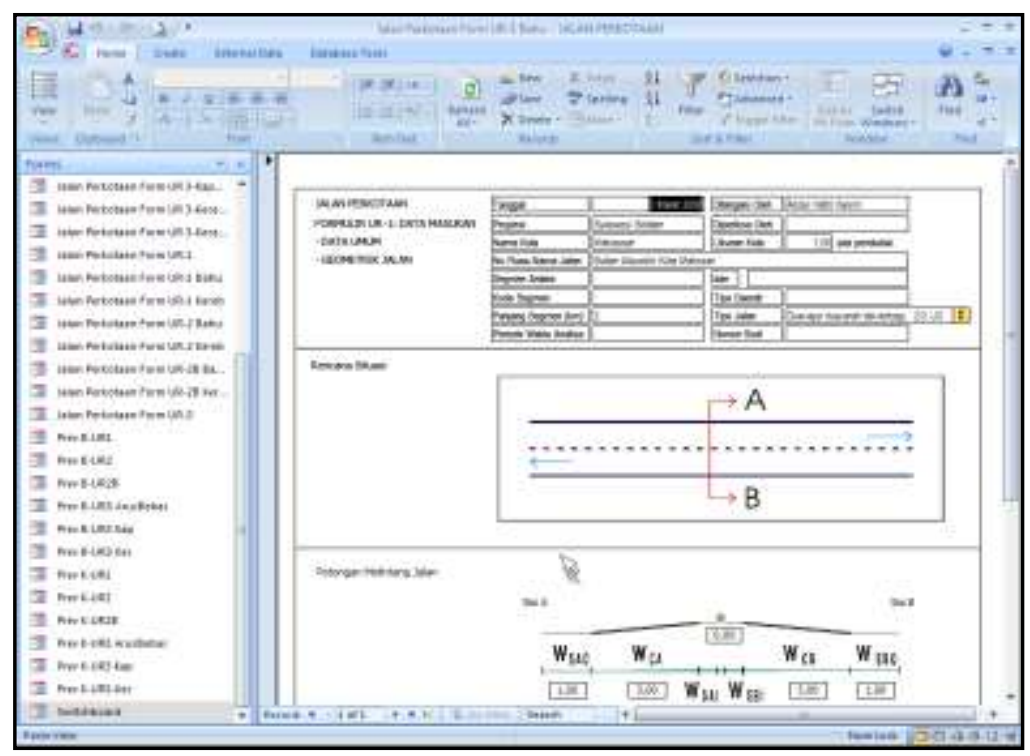

Gambar 7. Program Analisis Lalu Lintas ( KAJI )

Analisis ruas jalan dengan penggunaan KAJI terkendala dengan adanya keterbatasan KAJI yang tidak bisa dijalankan pada komputer-komputer mutakhir. Penggunaan program berbasis database dapat dilakukan untuk membuat program analisis ruas jalan. Program dibuat dengan bantuan Microsoft Access, yakni dengan membuat lembar-lembar kerja, yang dalam MKJI 1997 disebut formulir UR1, UR2 
dan UR3. Formulasi yang digunkan sama dengan yang terdapat dalam MKJI 1997 karena dasar pembuatannya adalah sistem database dengan Microsoft Access.

\section{Program Power Sim Versi 1.03}

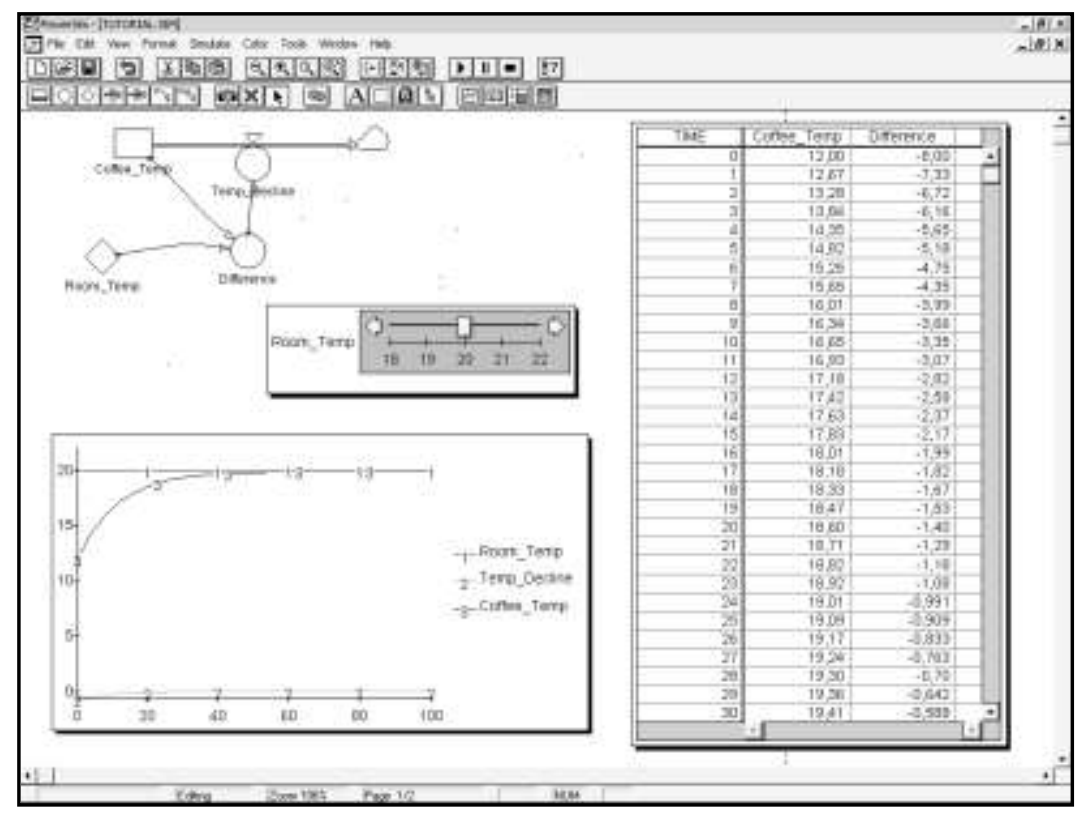

Gambar 8. Program Power Sim

a. Power Sim

Power Sim merupakan piranti lunak untuk membangun model simulasi bergerak. Paket piranti lunak ini memiliki banyak keistimewaan dan inovasi dalam ruang lingkup simulasi dan sistem dinamik.

b. Konsep Dasar

- Diagram : Dokumen asli (primary document) digunakan untuk pembuatan gambar, analisa, dan simulasi model.

- Equation (penyamaan) : Gambaran isi (text) dari model. 
- Function (fungsi) : Kelengkapan untuk menghitung satu atau lebih nilai yang memberi hasil 0 atau lebih alasan. topik fungsi menggambarkan manfaat yang diperoleh dari powersim.

- Model : Bentuk model yang digunakan untuk menggambarkan sistem nyata atau tidak.

- Object : Konsep dasar membangun dari dokumen powersim. digunakan untuk membangun struktur model, menunjukkan hasil simulasi, membuat diagram model, dan menukar informasi antar beberapa obyek.

- Simulasi : simulasi menggambarkan perkembangan variabel yang ada pada model. Powersim menghitung nilai variabel untuk setiap waktu berjalan dalam periode simulasi.

- Variabel : Model terdiri atas variabel-variabel yang merupakan jumlah dari sistem yang dijadikan model. Variabel ini memerlukan nilai yang dihitung setiap waktu dalam simulasi, tingkatan dan alat bantu variabel umumnya berubah sepanjang simulasi, sementara konstanta tetap.

\section{c. Bahasa Simulasi Power Sim}

Maksud bahasa Power Sim ini adalah membuat gambaran atau model dari sebuah sistem yang nyata atau tidak. Saat menyusun model, sistem yang telah digambar digunakan untuk membuat asumsi tentang sistem yang telah digambar tersebut. Model terdiri atas komponen yang saling berhubungan, disebut sebagai Variabel. Konstruksi model dibuat dengan menentukan variabel dan hubungan antar 
variabel. Bahasa gambar digunakan untuk membangun model di Editor Diagram Power Sim.

d. Menentukan Alat Bantu

Nilai alat bantu dihitung dengan mengevaluasi lambang-lambang matematis. Lambang-lambang ini dapat melibatkan operator, function, literal, dan referensi untuk variabel-variabel model.

Penggambaran informasi berkaitan dengan alat bantu menginformasikan ke sistem bahwa alat bantu tergantung pada variabel yang berhubungan dengannya. Dalam hal ini alat bantu $\mathrm{R}$ tergantung pada variabel $\mathrm{C}$ dan $\mathrm{L}$.

Saat pengeditan definisi $\mathrm{R}$, pengedit akan menampilkan $\mathrm{L}$ dan $\mathrm{C}$ dalam daftar input variabel. Ini berarti bahwa $\mathrm{R}$ tergantung $\mathrm{L}$ dan $\mathrm{C}$, secara kasar bahwa antara $\mathrm{L}$ dan $\mathrm{C}$ harus ada pada equasi penentuan R. Editor variabel definisi terbuka dengan double-click pada $\mathrm{R}$ ).

Penentuan alat bantu ditulis pada The Definition Field dari The Variabel Definition Editor. Definisi ini ditunjukkan dengan lambang matematis, yang harus melibatkan semua variabel yang tertulis dalam daftar input variabel.

e. Penentuan Konstanta

Konstanta digunakan untuk menentukan variabel yang tidak berubah sepanjang simulasi. Konstanta ditentukan dengan memasukkan sebuah literal sebagai lambang penentuan variabel. Sebuah alat bantu variabel otomatis berubah menjadi konstanta jika definisinya diubah menjadi literal. Suatu konstanta dapat tidak bergantung pada variabel lain. 


\section{f. Menentukan Level}

Perbedaaan level dari semua variabel ditulis dalam nilai yang cenderung berubah sepanjang simulasi. Level adalah pengumpul, diubah oleh input dan/atau output dari simulasi ke simulasi berikutnya.

Karena nilai level sering tergantung nilai level pada simulasi sebelumnya, kita membutuhkan beberapa nilai awal yang spsifik untuk level tersebut. Nilai awal ini akan digunakan dalam penghitungan nilai awal pada level. Pada semua simulasi yang sukses, nilai langsung level digunakan dalam kombinasi dengan aliran input dan/atau output level dalam membatasi nilai dari level pada langkah selanjutnya.

Nilai awal level dapat tergantung pada variabel lain dalam model. Ini diperoleh dengan menghubungkan hubungan informasi dari variabel-variabel lain ke simbol level. Keterkaitan informasi akan digunakan hanya dalam menghitung langkah awal simulasi. Inisialisasi hubungan ini dipisahkan dari hubungan informasi lain yang menggunakan a dotted arrow instead of solid.

g. Menyatukan Variabel

Dengan menyusun variabel sebagai satu kesatuan, kelompok nilai yang berelasi dapat ditunjukkan sebagai satu variabel. Penyatuan ini dapat berupa satu atau lebih dimensi. Kesatuan dengan satu dimensi disebut Vektor. Dan kesatuan yang lebih dari satu dimensi disebut Matrix.

h. Pengenalan Simulasi

Sistem yang dianalisis dengan bantuan model dinamik atau bergerak sering merupakan sistem yang kontinyu. Pada beberapa sistem, perubahan variabel dalam 
sistem yang berkelanjutan, misalkan; pergerakan planet, perubahan cuaca, pertumbuhan penduduk, dll. Pada sistem lain variabel sistem berubah dalam langkah pada waktu spesifik tertentu, misalkan; deposit bank, sistem pelayanan dan antrian, d1l.

Continuous system biasanya melibatkan level dan definisi dan bentuk berdasarkan kondisi variabel. Waktu dilanjutkan sampai simulasi menggunakan ukuran tetap dengan spesifik input.

Untuk menghitung perbedaannya kita dapat menggunakan hasil bagi $\mathrm{x} / \mathrm{t}$, yang memberi rata-rata kasar untuk bentuk gambar pada interval waktunya. Equasi yang dilambangkan dengan laju perubahan level variabel akan berdasar pada nilai yang muncul dari level-level pada fakta poin saat simulasi. Oleh karena itu turunannya digunakan pada interval waktunya. Laju perubahan ditunjukkan dengan pembatasan perbedaan hasil bagi saat $t$ bergerak mendekati 0 .

Metode intergrasi yang disediakan oleh Power Sim adalah Euler Integration, Runge_Kutta Second Order,Third, dan Fourth Integration Method yang mutakhir dengan Both Fixed dan Variabel Step Size.

Runge-Kutta Integration memiliki dua kelebihan. Pertama, sangat mudah untuk mengubah ukuran simulation step sepanjang simulasi dengan metode RungeKutta. Karena kebutuhan akan ukuran variabel simulasi dalam simulasi kombinasi sangat penting. Yang kedua, integrasi Runge-Kutta memulai sendiri, oleh karena itu tidak akan ada ketidakefisienan saat men-start ulang. Hal ini juga merupakan kepentingan dalam simulasi kombinasi. 


\section{BAB IV}

\section{HASIL PENELITIAN DAN PEMBAHASAN}

\section{A. Hasil Penelitian}

Penelitian dilaksanakan pada lokasi ruas Jalan Sultan Alauddin Kota Makassar. Untuk pengambilan data lapangan dilaksanakan setiap hari senin sebanyak 4 kali pengambilan terhitung mulai tanggal 3, 10, 17 dan 24 Maret 2008. Adapun data yang diperoleh sebagai berikut :

\section{Data Tipe Lingkungan}

Berdasarkan tata guna lahan dan aksebilitas jalan dari aktivitas sekitarnya, maka untuk ruas jalan Sultan Alauddin Kota Makassar dikategorikan sebagai tipe komersial (COM).

\section{Tipe Jalan}

2 jalur ; 4 lajur ; tak terbagi ( 4/2 UD )

\section{Kondisi Geometrik}

a. Lebar Jalan

- Arah Makassar - Sungguminasa =7,10 m

- Arah Sungguminasa - Makassar $\quad=7,80 \mathrm{~m}$

b. Lebar Bahu

- Arah Makassar - Sungguminasa = 4,10 m

- Arah Sungguminasa - Makassar = 2,10 m

c. Fasilitas Median = Tidak Ada 
d. Pemisah Arah lalu Lintas

e. Ukuran Kota

f. Tipe Alinyemen

\section{Hambatan Samping}

Frekuensi Kejadian Maksimal
$=70-30$

$=1,0-3,0$ Juta

$=$ Datar

$$
=1195 \mathrm{kali} / \mathrm{jam}
$$

\section{Arus lalu lintas jam puncak}

- Senin Pertama ( 3 Maret 2008 )
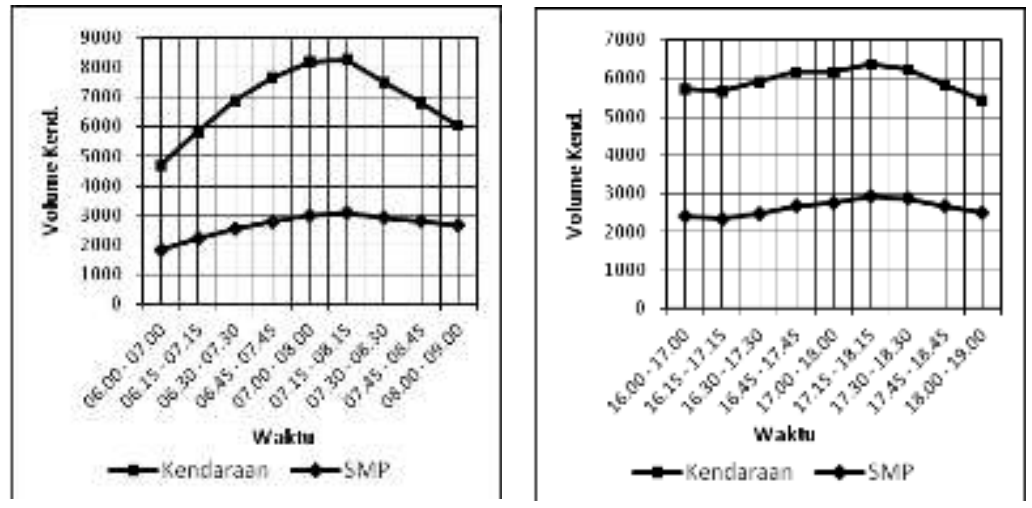

Periode Waktu ( 07.15 - 08.15 )

$=3078 \mathrm{smp} / \mathrm{jam}$

Periode Waktu ( 17.15 - 18.15 )

$=2932 \mathrm{smp} / \mathrm{jam}$

- Senin Kedua ( 10 Maret 2008 )
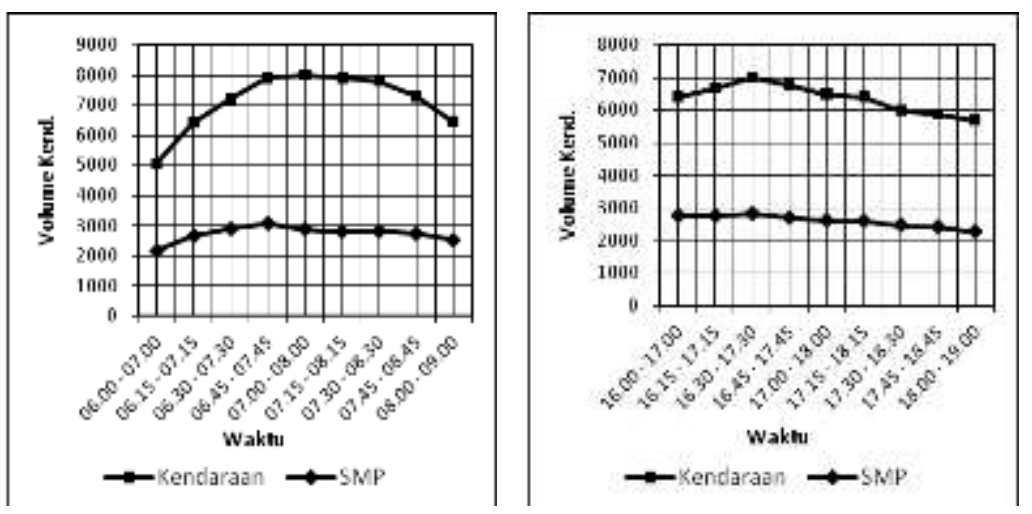
Periode Waktu ( 06.45 - 07.45 )

$=3077 \mathrm{smp} / \mathrm{jam}$

Periode Waktu (16.30 - 17.30$)$

$=2814 \mathrm{smp} / \mathrm{jam}$

- Senin Ketiga ( 17 Maret 2008 )

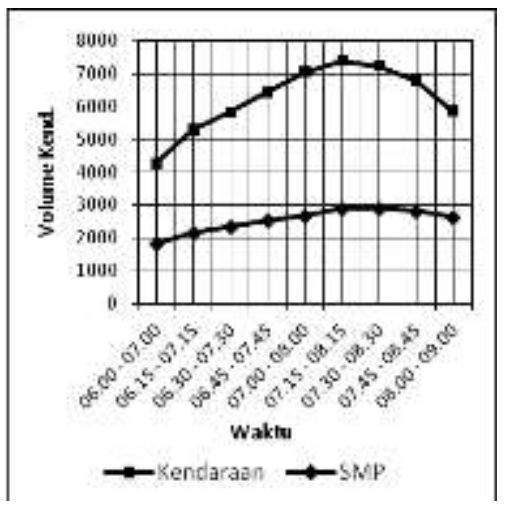

Periode Waktu ( 07.30 - 08.30 )

Periode Waktu ( 16.30 - 17.30$)$

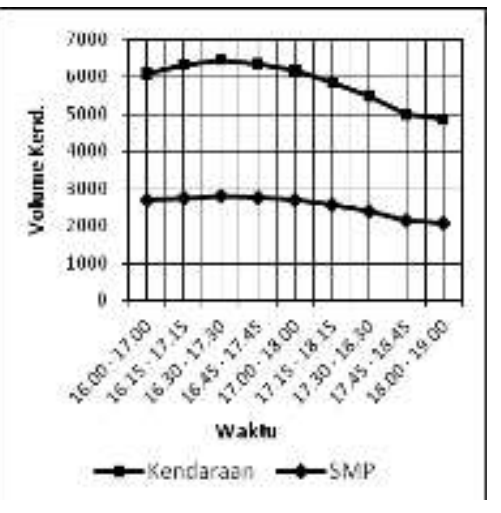

$=2892 \mathrm{smp} / \mathrm{jam}$

$=2792 \mathrm{smp} / \mathrm{jam}$

- Senin Keempat ( 24 Maret 2008 )

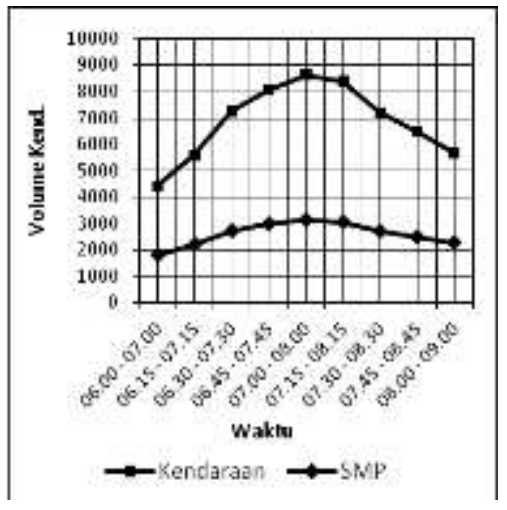

Periode Waktu ( 07.00 - 08.00 )

Periode Waktu ( 16.30 - 17.30$)$

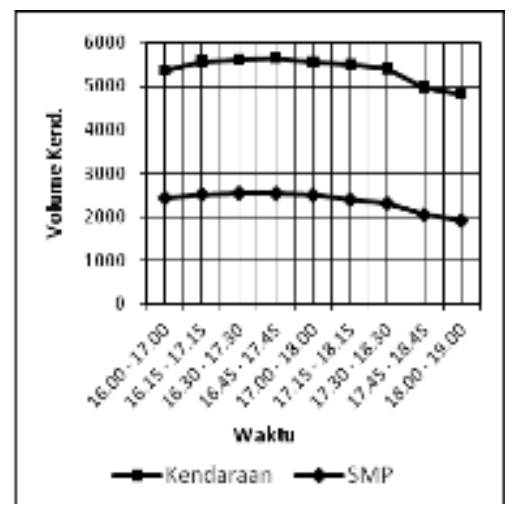

$=3122 \mathrm{smp} / \mathrm{jam}$

$=2544 \mathrm{smp} / \mathrm{jam}$ 


\section{B. Pembahasan Hasil Penelitian}

\section{Analisis Program Ruas Jalan KAJI :}

Program dibuat dengan bantuan Microsoft Access, yakni dengan lembar-lembar kerja, yang dalam MKJI 1997 disebut Formulir UR-1, UR-2, dan UR-3. Program tersebut digunakan untuk menganalisis data lapangan yang ada. Dari analisis tersebut diperoleh :

\begin{tabular}{|c|c|c|c|}
\hline $\begin{array}{c}\text { Kec. Arus Bebas } \\
\text { ( FV ) } \\
\text { km/jam }\end{array}$ & $\begin{array}{c}\text { Kapasitas } \\
\text { ( C ) } \\
\text { smp/jam }\end{array}$ & $\begin{array}{c}\text { Derajat } \\
\text { Kejenuhan } \\
(\boldsymbol{D S})\end{array}$ & $\begin{array}{c}\text { Kec. Kend. } \\
(\mathbf{V} \text { LV }) \\
\mathbf{~ k m / j a m ~}\end{array}$ \\
\hline 53,90 & 5803,56 & 0,54 & 48,91 \\
\hline
\end{tabular}

(Sumber : Hasil Analisis Program Ruas Jalan KAJI)

\section{Analisis Power Simulation}

Power Sim. merupakan piranti lunak untuk membangun model simulasi bergerak. Paket piranti lunak ini digunakan untuk analisis pertumbuhan arus lalu lintas. Dari analisis tersebut diperoleh :

\begin{tabular}{|c|c|c|}
\hline $\begin{array}{c}\text { Senin } \\
\text { Ke- }\end{array}$ & $\begin{array}{c}\text { Arus Lalin } \\
\text { (smp/jam) }\end{array}$ & \multirow{2}{*}{ Ket. } \\
\hline 0 & 3078 & \multirow{2}{*}{$\begin{array}{c}\text { Data } \\
\text { Lapangan }\end{array}$} \\
\hline 1 & 3093 & \\
\hline 2 & 3107 & \\
\hline 3 & 3122 & \\
\hline
\end{tabular}

( Sumber : Hasil Penelitian)

\begin{tabular}{|c|c|l|}
\hline $\begin{array}{c}\text { Senin } \\
\text { Ke- }\end{array}$ & $\begin{array}{c}\text { Arus Lalin } \\
\text { (smp/jam) }\end{array}$ & \multicolumn{1}{|c|}{ Ket. } \\
\hline 52 & 3953 & Tahun ke-I \\
\hline 104 & 5077 & Tahun ke-II \\
\hline 156 & 6520 & Tahun ke-III \\
\hline 208 & 8374 & Tahun ke-IV \\
\hline 260 & 10755 & Tahun ke-V \\
\hline 312 & 13813 & Tahun ke-VI \\
\hline 354 & 16907 & Tahun ke-VII \\
\hline 416 & 22785 & Tahun ke-VIII \\
\hline 468 & 29264 & Tahun ke-IX \\
\hline 520 & 37585 & Tahun ke-X \\
\hline
\end{tabular}

(Sumber : Hasil Program Power Sim.) 


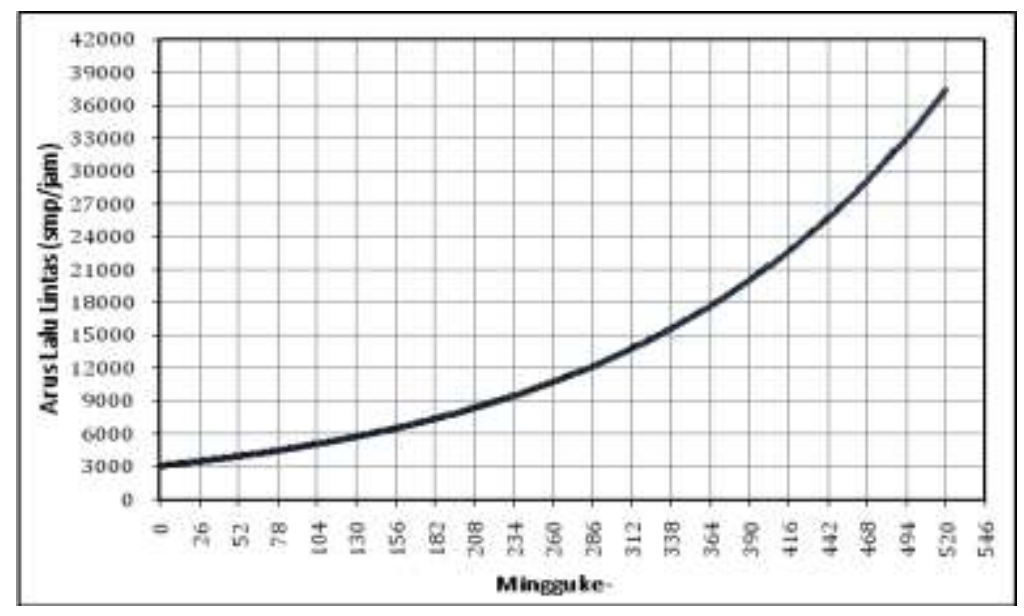

Gambar 9. Grafik Analisis Data Dengan Power Simulation

Dari hasil analisa data lapangan terlihat bahwa derajat kejenuhan atau degree of saturation (DS) pada ruas jalan Sultan Alauddin $=0,54<1,00$, berarti tingkat pelayanan pada ruas jalan tersebut masuk dalam kategori $\mathrm{C}$ dengan batas lingkup (V/C) 0.45 - 0.74 yaitu Kondisi arus stabil, tetapi kecepatan operasi dan gerak kendaraan dipengaruhi besar volume lalu lintas. Pengemudi dibatasi dalam memilih kecepatan. Dari data lapangan kemudian di analisis dengan program Power Sim diperoleh arus lalu lintas setiap senin sampai dengan senin ke-520 atau 10 tahun dengan asumsi 1 tahun $=52$ Senin .

\begin{tabular}{|l|c|c|c|c|}
\hline Kondisi I & $\begin{array}{c}\text { Kec. Arus } \\
\text { Bebas } \\
(\mathbf{F V}) \\
\text { km/jam }\end{array}$ & $\begin{array}{c}\text { Kapasitas } \\
(\mathbf{C}) \\
\text { smp/jam }\end{array}$ & $\begin{array}{c}\text { Derajat } \\
\text { Kejenuhan } \\
(\boldsymbol{D S})\end{array}$ & $\begin{array}{c}\text { Kec. Kend. } \\
(\mathbf{V ~ L V ~}) \\
\mathbf{~ k m / j a m ~}\end{array}$ \\
\hline Senin ke-52 & 53,90 & 5803,56 & 0,68 & 46,33 \\
\hline Senin ke-104 & 53,90 & 5803,56 & 0,87 & 41,74 \\
\hline Senin ke-132 & 53,90 & 5803,56 & 1,00 & 37,99 \\
\hline
\end{tabular}

( Sumber : Hasil Analisis Program Ruas Jalan KAJI ) 
Senin ke-52 derajat kejenuhan $(d s)=0,68<1,00$. Tingkat pelayanan masuk pada kategori C yaitu kondisi arus stabil, tetapi kecepatan operasi dan gerak kendaraan dipengaruhi besar volume lalu lintas. Pengemudi dibatasi dalam memilih kecepatan

Senin ke-104 derajat kejenuhan $(d s)=0,87<1,00$. Tingkat pelayanan masuk pada kategori E yaitu volume lalu lintas sudah mendekati kapasitas ruas jalan, arus lalu lintas tak stabil, pergerakan lalu lintas kadang terhambat.

Senin ke-132 derajat kejenuhan $(d s)=1,00$. Tingkat pelayanan pada jalan tersebut masuk dalam kategori F yaitu Kondisi arus lalu lintas berada dalam keadaan dipaksakan (forced-flow), kecepatan relatif rendah, arus lalu lintas sering terhenti sehingga menimbulkan antrian yang panjang. Tingkat kejenuhan jatuh pada senin ke132 dengan arus lalu lintas 5809 smp/jam yang terlihat dari derajat kejenuhan yang diperoleh.

Dengan kondisi yang demikian diperlukan pelebaran jalan agar kondisi arus lalu lintas dapat dikendalikan. Kondisi I dimana jalan masih dalam kondisi awal, kondisi II dimana ruas jalan dalam kondisi telah diperlebar. Seperti terlihat pada gambar 10 dan 11.

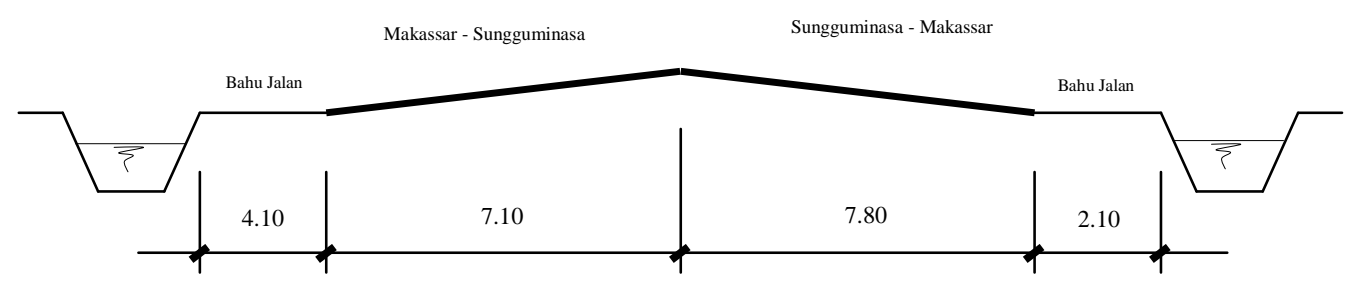

Gambar 10. Kondisi I 


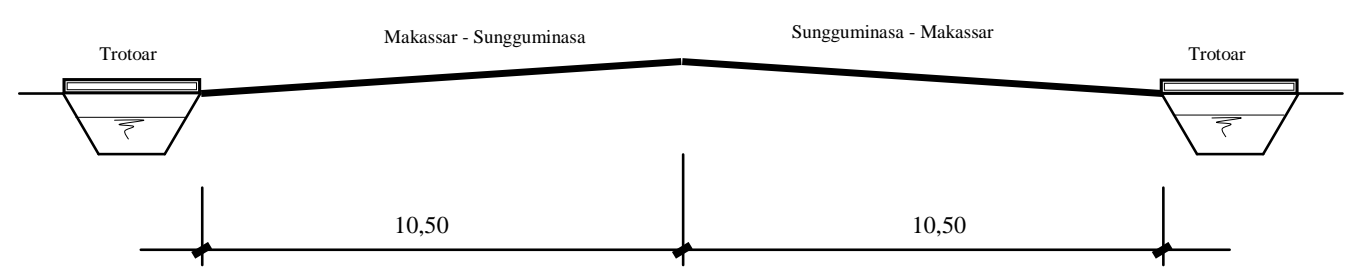

Gambar 11. Kondisi II

Kondisi I yaitu ruas jalan masih keadaan awal, kapasitas ruas jalan tersebut tak mampu mendistribusikan arus lalu lintas dengan optimal hingga senin ke-132 sehingga diperlukan pelebaran jalan.

Kondisi II yaitu ruas jalan setelah pelebaran, jumlah lajur lalu intas bertambah menjadi 3 lajur dalam 1 jalur sehingga kapasitas ruas jalan juga bertambah dari 6000 smp/jam menjadi 9000 smp/jam.

\begin{tabular}{|c|c|c|c|c|}
\hline Kondisi & $\begin{array}{c}\text { Kec. Arus } \\
\text { Bebas } \\
(\text { FV }) \\
\text { km/jam }\end{array}$ & $\begin{array}{c}\text { Kapasitas } \\
(\mathbf{C}) \\
\text { smp/jam }\end{array}$ & $\begin{array}{c}\text { Derajat } \\
\text { Kejenuhan } \\
(\boldsymbol{D S})\end{array}$ & $\begin{array}{c}\text { Kec. Kend. } \\
(\mathbf{V} \text { LV }) \\
\mathbf{~ k m / j a m ~}\end{array}$ \\
\hline I & 53,90 & 5803,56 & 1,00 & 37,99 \\
\hline II & 57,34 & 7867,80 & 0,74 & 46.00 \\
\hline
\end{tabular}

(Sumber : Hasil Analisis Program Ruas Jalan KAJI)

Dari hasil pelebaran jalan diperoleh penambahan kapasitas jalan sebesar 2064,24, dari 5803,56 menjadi 7867,80. Derajat kejenuhan pun menjadi lebih rendah sebesar 0,26 dari 1,00 menjadi 0,74 . Tingkat pelayanan dari kategori $\mathrm{F}$ menjadi kategori C yaitu kondisi arus stabil, tetapi kecepatan operasi dan gerak kendaraan dipengaruhi besar volume lalu lintas, pengemudi dibatasi dalam memilih kecepatan. 
Karena pertumbuhan jumlah kendaraan yang semakin meningkat maka kapasitas ruas jalan yang ada semakin rendah dari tahun ke tahun hingga tak mampu lagi mendistribusikan seluruh arus lalu lintas yang melintas.

\begin{tabular}{|c|c|c|c|c|}
\hline Kondisi II & $\begin{array}{c}\text { Kec. Arus } \\
\text { Bebas } \\
(\mathbf{F V}) \\
\text { km/jam }\end{array}$ & $\begin{array}{c}\text { Kapasitas } \\
(\mathbf{C}) \\
\text { smp/jam }\end{array}$ & $\begin{array}{c}\text { Derajat } \\
\text { Kejenuhan } \\
(\boldsymbol{D S})\end{array}$ & $\begin{array}{c}\text { Kec. Kend. } \\
(\mathbf{V} \text { LV }) \\
\mathbf{~ k m / j a m ~}\end{array}$ \\
\hline Senin ke-132 & 57,34 & 7867,80 & 0,74 & 47,00 \\
\hline Senin ke-156 & 57,34 & 7867,80 & 0,83 & 44,00 \\
\hline Senin ke-195 & 57,34 & 7867,80 & 1,00 & 32,00 \\
\hline
\end{tabular}

(Sumber : Hasil Analisis Program Ruas Jalan KAJI)

Senin ke-156 derajat kejenuhan $(d s)=0,83<1,00$. Tingkat pelayanan pada ruas jalan masuk dalam ketegori D dengan kondisi arus lalu lintas mendekati tidak stabil, kecepatan operasi menurun relatif cepat akibat hambatan yang timbul dan kebebasan bergerak relatif kecil, V/C masih dapat ditolerir.

Senin ke- 195 derajat kejenuhan $(d s)=1,00$. Tingkat pelayanan pada jalan tersebut masuk dalam kategori F yaitu Kondisi arus lalu lintas berada dalam keadaan dipaksakan (forced-flow), kecepatan relatif rendah, arus lalu lintas sering terhenti sehingga menimbulkan antrian yang panjang. Tingkat kejenuhan jatuh pada senin ke195 dengan arus lalu lintas $7866 \mathrm{smp} / \mathrm{jam}$ yang terlihat dari derajat kejenuhan yang diperoleh.

Dari analisis yang ada maka dapat ditarik kesimpulan bahwa kinerja ruas Jalan Sultan Alauddin untuk kondisi geometrik sebelum pelebaran atau masih dalam 
kondisi I hanya mampu mendistribusikan arus lalu lintas hingga senin ke-132 setelah itu geometrik jalan perlu diperlebar atau dalam kondisi II.

Dalam kondisi II setelah pelebaran ruas Jalan Sultan Alauddin hanya mampu bertahan mendistribusikan arus lalu lintas yang meningkat hingga senin ke-195. 


\section{BAB V}

\section{KESIMPULAN DAN SARAN}

\section{A. Kesimpulan}

Berdasarkan hasil penelitian dan analisa hasil pengambilan data lapangan pada lokasi ruas Jalan Sultan Alauddin Kota Makassar, dapat diambil kesimpulan sebagai berikut :

1. Arus lalu lintas pada Jalan Sultan Alauddin untuk kondisi geometrik I masuk dalam tingkat pelayanan kategori C, pada senin ke-132 tingkat pelayanan masuk kategori F yang merupakan titik jenuh jalan. Kondisi geometrik II, setelah ruas jalan diperlebar sebagai solusi alternatif, tingkat pelayanan kategori $\mathrm{F}$ menjadi kategori C hingga mencapai titik jenuh pada senin ke-195 dengan tingkat pelayanan kategori $\mathrm{F}$.

2. Pertumbuhan arus lalu lintas pada ruas Jalan Sultan Alauddin dengan menggunakan Program Power Simulation diperkirakan 0,48\% per minggu dengan kecenderungan peningkatan jumlah arus lalu lintas dari tiap minggu. 


\section{B. Saran}

1. Menerapkan pola arus distribusi kendaraan yang membuat seluruh kendaraan lambat dan cepat terpisah dalam satu lajur lalu lintas.

2. Pengaturan arus pada Terminal Mallengkeri khususnya pada saat keluar dan masuknya kendaraan yang melewati ruas Jalan Sultan Alauddin Kota Makassar.

3. Pemasangan rambu-rambu peringatan dilarang parkir/berhenti di sepanjang sisi jalan khususnya untuk angkutan kota yang sedang menunggu dan menurungkan penumpang.

4. Perlu diadakan penelitian lebih lanjut tentang kondisi di ruas Jalan Sultan Alauddin Kota Makassar. 


\section{DAFTAR PUSTAKA}

Abubakar, Iskandar. DKK. 1999. Rekayasa Lalu Lintas. Direktorat Bina Sarana Lalu Lintas Angkutan Kota. Jakarta.

BAPPEDA Kota Makassar. Infrastruktur Kota Makassar. Transportasi dan Jalan. $\begin{array}{ll}\text { (http://www.bappedamakassar.net/infrastruktur_kota.htm, diakses } & 13\end{array}$ November 2007)

BAPPEDA Kota Makassar. Jumlah Penduduk dan Laju Pertumbuhan Penduduk dirinci Menurut Kecamatan di Kota Makassar. (http://www.bappedamakassar.net/simrenas/simrenas,3,1,1.htm, diakses 13 November 2007)

BAPPEDA Kota Makassar. Jumlah Penduduk di Kota Makassar. (http://www.bappeda- makassar.net/simrenas_grafik/grafik_simrenas,3,1.htm, diakses 13 November 2007)

Direktorat Jenderal Bina Marga, Departemen Pekerjaan Umum RI. 1992. Standar Perencanaan Geometrik Untuk Jalan Perkotaan. Direktorat Pembinaan Jalan Kota. Jakarta

Direktorat Jenderal Bina Marga, Departemen Pekerjaan Umum RI. 1990. Panduan Penentuan Klasifikasi Fungsi Jalan di Wilayah Perkotaan. Direktorat Pembinaan Jalan Kota. Jakarta

Direktorat Jenderal Bina Marga, Departemen Pekerjaan Umum RI. 1990. Panduan Survey dan Perhitungan Waktu Perjalanan Lalu Lintas. Direktorat Pembinaan Jalan Kota. Jakarta

Direktorat Jenderal Bina Marga, Departemen Pekerjaan Umum RI. 1997. Manual Kapasitas Jalan Indonesia (MKJI). Sweroad dan PT. Bina Karya. Jakarta.

Hendarto, Sri, DKK. Catatan Kuliah Dasar-Dasar Transportasi. Bandung : ITB 
Ing, Tan, Lie \& Efendi, Indra, Rachman. 2007. Evaluasi Kinerja Jalan Jendral Ahmad Yani Depan Pasar Kosambi Bandung. Jurnal Teknik sipil Universitas Kristen Maranatha. Volume 3 Nomor 1, April 2007 : 1-102. (http://www.jurnalsipilukm.tripod.com/v03n1.html, diakses 04 Agustus 2007)

Khisty C Jotin. \& Lall B Kent. 2005. Dasar-Dasar Rekayasa Transportasi. Jilid Pertama, Edisi Ketiga, Jakarta : Erlangga.

Morlok, Edward, K. 1991. Pengantar Teknik dan Perencanaan Transportasi, Jakarta: Erlangga.

Munawar, Ahmad. 2005. Program Komputer Untuk Analisis Lalu Lintas. Edisi Kedua, Yogyakarta : Beta Ofset.

Munawar, Ahmad. 2004. Manajemen Lalu Lintas Perkotaan. Yogyakarta: Beta Ofset.

Ruslan, DKK. 2006. Panduan Penulisan Skripsi dan Tugas Akhir Fakultas Teknik Universitas Negeri Makassar. Fakultas. Makassar : FT UNM

Sukirman, Silvia.1999. Perkerasan Lentur Jalan Raya. Bandung : Nova

Sukirman, Silvia. 1999. Dasar-Dasar Perencanaan Geometrik Jalan. Bandung : Nova

Tamin,O,Z. Soedirdjo, Titi, Liliani. Hidayat, Hedi. Kusumawati, Aine. Pengaruh Perparkiran di Badan Jalan (on-street parking) Terhadap Kinerja Ruas Jalan : Studi Kasus di DKI-Jakarta. (http://www.digilib.itb.ac.id/files/disk1/37/ jbptitbpp-gdl-grey-1992-48ofyarzta-1845-1992_gl_-8, diakses 23 Juli 2007)

Tamin,O, Z. Rahman, Harmein \& Frazila, Russ, Bona. Kajian Kelayakan Jalur Lintas Selatan di Propinsi Jawa Timur. (http://www.digilib.itb.ac.id/files/disk1/37/ jbptitbpp-gdl-grey-1999-05ofyarzta-1844-1999_gl_-5, diakses 30 Juli 2007) 
Tamin,O,Z. Metodologi Peramalan Lalu Lintas Perkotaan untuk Negara Berkembang. (http://www.digilib.itb.ac.id/files/disk1/37/jbptitbpp-gdl-grey-1992-48 ofyarzta-1845-1992_gl_-8.pdf, diakses 23 Juli 2007)

Tamin,O,Z. \& Nahdalina. Analisis Dampak Lalu Lintas (ANDALL). (http://www.digilib.itb.ac.id/files/disk1/37/jbptitbpp-gdl-grey-1998-14 ofyarzta-1845-1998_gl_-4, diakses 30 Juli 2007)

PEMKOT Makassar. Makassar dalam Angka 2005. Transportasi dan Komunikasi. (http://www.makassarkota.go.id/download/bab_08_transportasi_\&_komunika si.pdf, diakses 13 November 2007)

PEMKOT Makassar, BAPEDDA Kota Makassar, BPS Kota Makassar. Makassar dalam Angka 2007. (http://www.makassarkota.go.id/download.pdf, diakses 10 Juni 2008)

Wibowo, Sony, Sulaksono, DKK. 2001. Pengantar Rekayasa Jalan. Bandung : ITB 


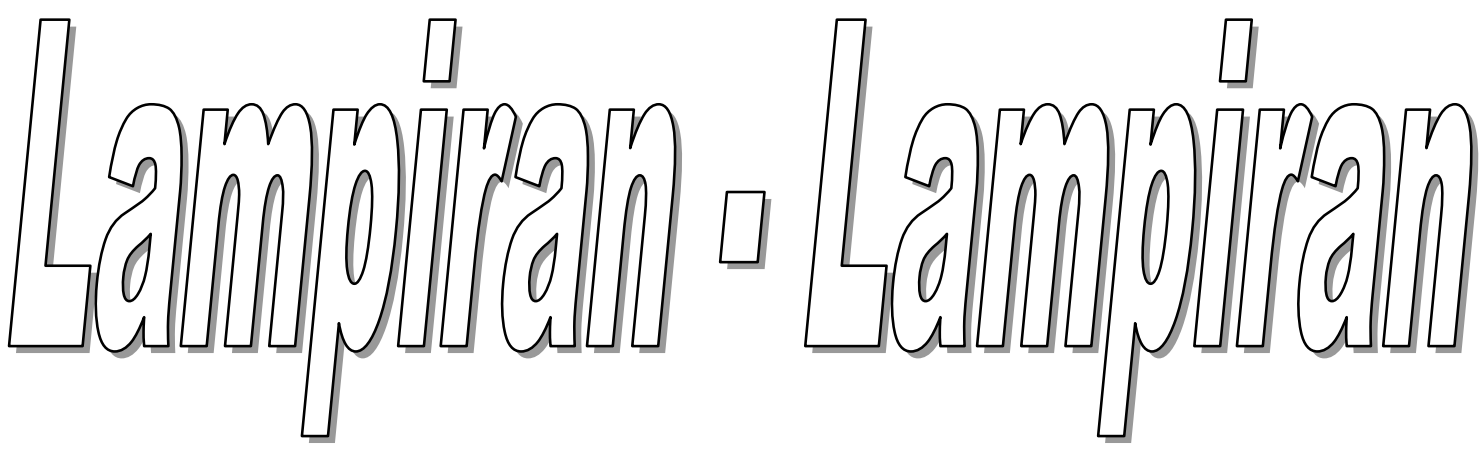



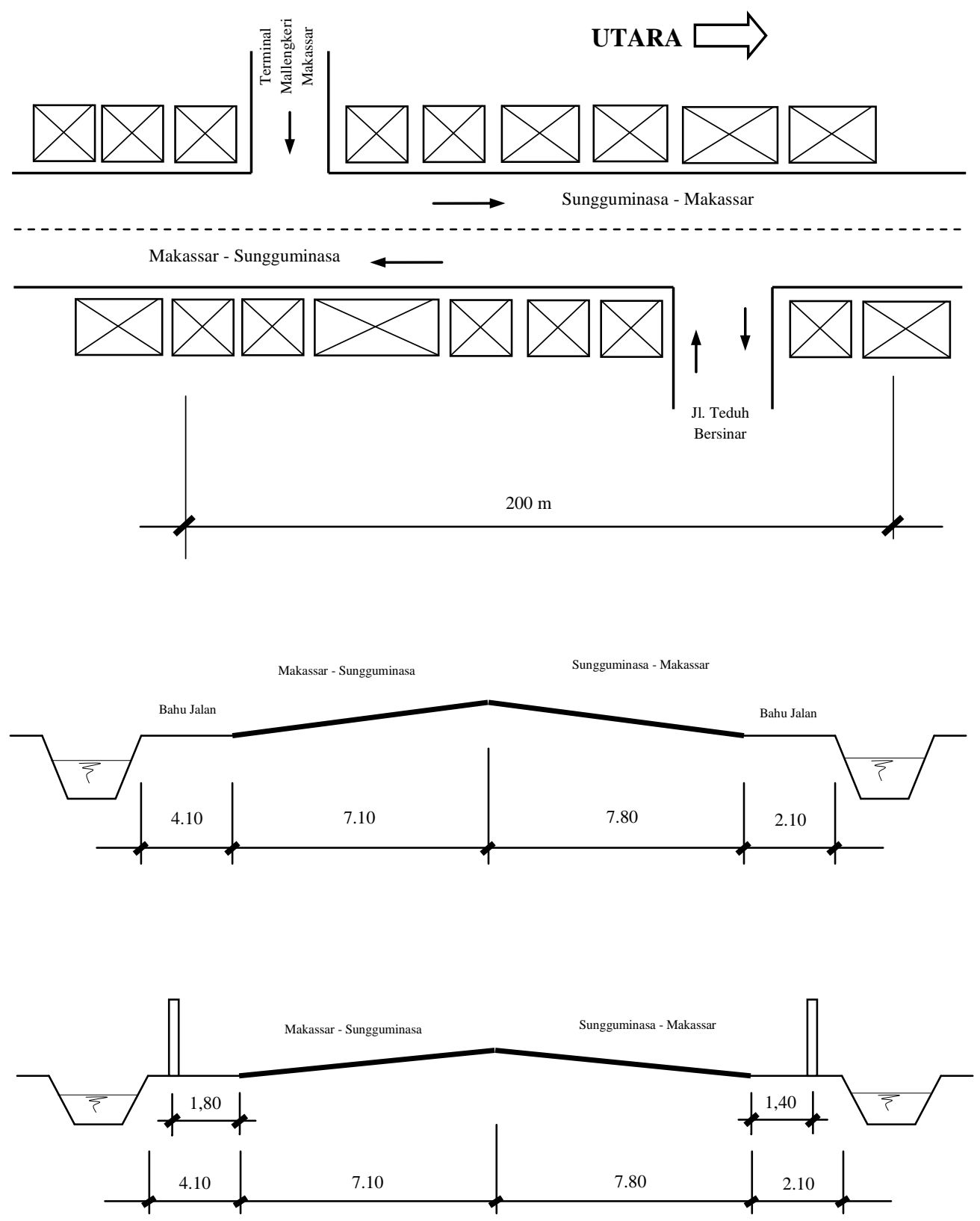

Sketsa Lokasi Penelitian 


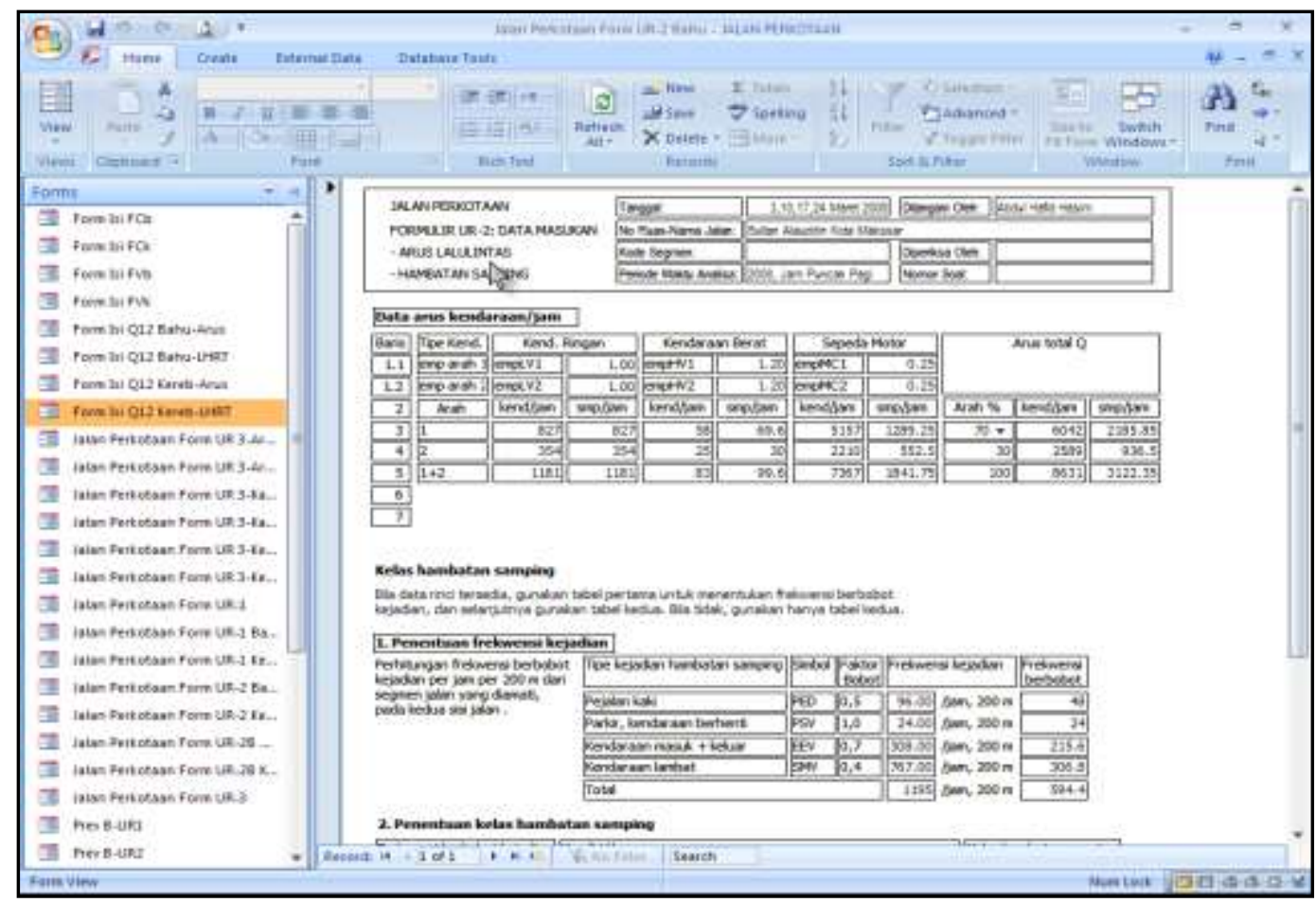

\section{Program Analisis Ruas Jalan KAJI}

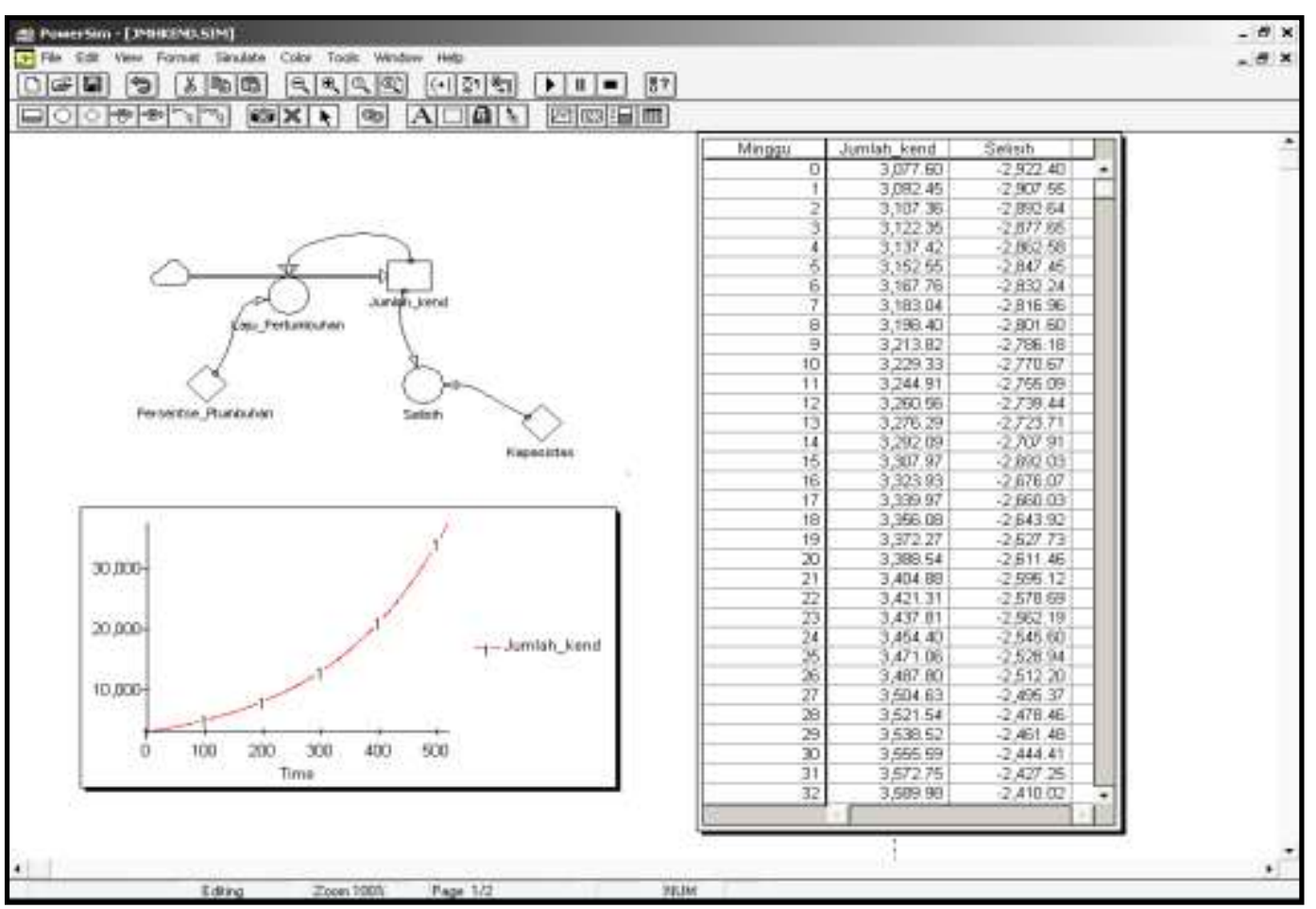

Program Analisis Power Simulation 